\title{
Assessment of differences between DNA content of cell-cultured and freely suspended oocysts of Cryptosporidium parvum and their suitability as DNA standards in qPCR
}

\author{
Ian D. Woolsey ${ }^{1 *}$, Berit Blomstrand ${ }^{2}$, Øivind Øines ${ }^{1}$ and Heidi L. Enemark
}

\begin{abstract}
Background: Although more modern methods are available, quantitative PCR (qPCR) is reproducible, sensitive and specific with instruments and expertise readily available in many laboratories. As such, the use of qPCR in Cryptosporidium research is well established and still widely used by researchers globally. This method depends upon the generation of standards at different concentrations to generate standard curves subsequently used for the quantification of DNA.

Methods: We assessed four types of DNA template used to generate standard curves in drug screening studies involving Cryptosporidium spp.: (i) serially diluted Cryptosporidium parvum oocysts (106-1); (ii) diluted template DNA from pure oocysts ( $\times 10-\times 10^{6}$ dilution of $10^{6}$ oocyst DNA template); (iii) oocysts incubated in human ileocecal adenocarcinoma (HCT-8) cells $\left(10^{5}-1\right.$ and $\left.5 \times 10^{4}-50\right)$; and (iv) diluted DNA template $\left(5 \times 10^{4}\right)$ from cell culture incubated parasites $(\times 10-\times 1000)$.

Results: Serial dilutions of both cell culture and pure oocyst suspension DNA template yielded better linearity than cell culture derived standards, with dilutions of $10^{6}$ oocysts exhibiting similar quantification cycle (Cq) values to those obtained from DNA template dilutions of $10^{6}$ oocysts. In contrast, cell culture incubated oocysts demonstrated significantly higher DNA content than equivalent freely suspended oocysts and diluted DNA template from both cell culture derived and freely suspended oocysts across numerous concentrations.

Conclusions: For many studies involving Cryptosporidium, only relative DNA content is required and as such, the superior linearity afforded by freely suspended oocysts and diluted DNA template (from either cell culture derived standards or freely suspended oocysts) will allow for more accurate relative quantification in each assay. Parasite division in the cell culture standards likely explains the higher DNA content found. These standards, therefore, have the potential to more accurately reflect DNA content in cell culture assays, and despite more modern methods available for absolute quantification, i.e. droplet digital PCR (ddPCR), the ubiquity of qPCR for the foreseeable future encourages further investigation into the reduced linearity observed in these standards such as varying oocyst seeding density, non-linear growth rates and assay efficiency.
\end{abstract}

Keywords: Cryptosporidium, HCT-8, Cell culture, qPCR

*Correspondence: ian.woolsey@vetinst.no

1 Department of Animal Health and Food Safety, Norwegian Veterinary

Institute, Ullevålsveien 68, 0454 Oslo, Norway

Full list of author information is available at the end of the article

c) The Author(s) 2019. This article is licensed under a Creative Commons Attribution 4.0 International License, which permits use, sharing, adaptation, distribution and reproduction in any medium or format, as long as you give appropriate credit to the original author(s) and the source, provide a link to the Creative Commons licence, and indicate if changes were made. The images or other third party material in this article are included in the article's Creative Commons licence, unless indicated otherwise in a credit line to the material. If material is not included in the article's Creative Commons licence and your intended use is not permitted by statutory regulation or exceeds the permitted use, you will need to obtain permission directly from the copyright holder. To view a copy of this licence, visit http://creativeco mmons.org/licenses/by/4.0/. The Creative Commons Public Domain Dedication waiver (http://creativecommons.org/publicdomain/ zero/1.0/) applies to the data made available in this article, unless otherwise stated in a credit line to the data. 


\section{Background}

Protozoan parasites of the genus Cryptosporidium are a significant cause of enteric disease in humans and animals globally [1]. In humans, cryptosporidiosis is considered the second leading cause of diarrhoea and death in children after rotavirus [2]. Cryptosporidium spp. is ranked the fifth food-borne parasite in importance in Europe after Echinococcus spp. (E. granulosus and E. multilocularis), Toxoplasma gondii, and Trichinella spiralis based on the FAO/WHO criteria [3]. Cryptosporidium spp. are transmitted via the faecal-oral route and oocysts may remain viable in the environment for long periods of time [4]. Oocysts are resistant to commonly used disinfectants and no vaccines are available $[5,6]$. At present, treatment options are insufficient and vary between countries, with only one drug approved for use, nitazoxanide (Alinia ${ }^{\circledR}$, Romark L.C., Tampa, USA) in humans and halofuginone lactate (Halocur ${ }^{\circledR}$, Intervet Productions S.A., Igovilles, France; Halagon ${ }^{\circledR}$, Divasa-Farmavic, S.A., Barcelona, Spain; Kriptazen ${ }^{\circledR}$, Virbac, Carros, France), and paromomycin (Parofor ${ }^{\circledR}$, Huvepharma NV, Sofia, Bulgaria) in calves, respectively. However, none of the drugs are able to completely prevent or cure the disease $[1,7]$.

Numerous methods have been employed to detect the presence of Cryptosporidium oocysts in stool or water samples for diagnostic purposes and water quality evaluations, to assess their infectivity, and to screen potential compounds for anti-Cryptosporidium efficacy (e.g. [8, 9]). The use of cell culture for the assessment of Cryptosporidium growth is widely established and in addition to determining the presence and varying infectivity of oocysts, this experimental model allows the screening of candidate compounds against Cryptosporidium spp. more economically than in vivo studies [10, 11]. Cell culture approaches allow different parasite stages to be exposed to various compounds and to different concentrations in vitro so that their relative growth compared to an unexposed control may be determined (e.g. [12, 13]). This method has been supplemented by various methods for quantification of the parasite, including the use of immunofluorescence [12, 14] and conventional polymerase chain reaction (PCR) $[15,16]$. Successful development of $C$. parvum was first reported in cell culture by Current \& Haynes in 1984 [17]. Although many improvements have been made since then, large-scale parasite reproduction in cultured systems is yet to be achieved. Oocyst production in cell lines has been described but much information regarding the development of the different parasite stages remain difficult to interpret. Due to these problems, complimentary studies are often performed and mouse models are still considered the gold standard for evaluation of infectivity of Cryptosporidium oocysts. However, cell culture systems can still provide valuable information regarding Cryptosporidium biology much more quickly and affordably than animal models [18].

Quantitative PCR (qPCR) represents an important improvement over conventional PCR [19] with this method allowing for the quantification of DNA target in real time and has proven to be reproducible, sensitive and specific [20]. Real-time instruments are often already available in laboratories as a wide variety of molecular methods have been developed on these platforms, and as $\mathrm{qPCR}$ reactions can be easier to automate, this also allows for higher throughput of samples. One key drawback of this platform, when used for quantification, is the need for several standards at different concentrations (representing the dynamic range of the assay) to ensure generation of standard curves to allow the subsequent quantification of DNA in the samples [21], and these need to be included in each PCR run to address inherent variability and performance of the PCR. These small, random and technical variations may arise due to minor differences in running conditions, instrument reproducibility, variation in the samples investigated or variations of concentrations of components in the PCR reactions.

Methods employed to make controls that are used as templates to establish standard curves for Cryptosporidium qPCR quantification, vary from serial dilutions of template DNA extracted from a known stock concentration of oocysts [21-23], serial dilution of a known stock concentration of oocysts and subsequent extraction [24, 25], template prepared from inoculation of serial diluted oocyst suspensions into cell culture [26-28], the serial dilution of extracted template DNA from a known quantity of oocysts inoculated onto cell culture [27], or serial dilution of cloned amplification targets in plasmids $[27,29]$.

Cryptosporidium parvum is a proliferative parasite, undergoing both asexual and sexual division with infective sporozoites developing into trophozoites, meronts and 6-8 merozoites each (and therefore contain approximately 6-8 nuclei each) [30], each of which differ in volume compared with that of the initial invading sporozoite $[13,31]$. Thus, the applicability of these different standards and careful attention to how they are prepared is necessary. For investigations aiming to merely identify and quantify oocysts from stool or water samples, it would be logical to use standards that are prepared from serial dilutions of a known quantity of oocysts (or serial dilutions of extracted template DNA from a known quantity of oocysts), and this approach has been reported from several studies [21, 25]. Similarly, serial dilutions of a known quantity of oocysts incubated in cell culture, under similar conditions would logically improve the assessment of the presence of any comparative inhibitory potential of these compounds against Cryptosporidium 
oocysts. Such disinfection/inactivation studies utilising cell culture have previously been reported [10, 24, 26, 28].

Some studies utilise serial dilutions of free oocysts as standards for parasite samples after being grown in cell culture, or for parasite development in cell-free culture [22-24]. As the relative, rather than absolute quantification, is relevant for compound screening and disinfection studies as only significant effects on parasites are relevant, the use of such standards could still be a feasible alternative. High variation is inherent within Cryptosporidium cell culture assays [9] and could make any attempts of generating precise and uniform standards for accurate parasite count challenging.

In qPCR reactions, the quantity of a specific DNA target in a sample is calculated from the observed quantification cycle $(\mathrm{Cq})$ value and compared to the quantification cycle of known standards. It is important that the sample DNA is run in parallel under identical conditions with the group of controls. The accuracy of the data extrapolated from these experiments is therefore highly dependent on both the accuracy of the DNA standard quantification, and the quality of the standard curve generated [32]

Recently, digital droplet PCR (ddPCR) has been a method that somewhat overcame the variety of errors introduced when making these standard curves [21]. In ddPCR, partitioning of the samples into thousands of single droplets containing mostly one or no target DNA molecules, and subsequently performing a PCR reaction in this droplet, can eliminate the errors introduced by using standard curves [21]. Although the ddPCR approach allows highly accurate concentration calculations, the higher costs associated with the additional purchase of special ddPCR instruments and reagents could be considerable for a laboratory. Additionally, qPCR enables increased throughput compared to ddPCR platforms [21] and it is therefore likely qPCR will remain a widely relevant and useful platform in the future. In an effort to assess the appropriateness of these standards in future experiments screening for candidate compounds against Cryptosporidium spp. in vitro, we determined the differences in parasite DNA content using qPCR and data from Cq-values from four different standards: (i) serially diluted Cryptosporidium parvum oocysts; (ii) diluted template DNA from pure oocysts; (iii) equivalent concentrations of oocysts incubated in cell culture; and (iv) diluted DNA template from cell culture incubated parasites.

\section{Methods}

\section{Parasite material}

Cryptosporidium parvum oocysts (Iowa strain) were purchased from Bunch Grass Farm (ID, Deary, USA) and stored in $50 \mathrm{ml}$ phosphate-buffered saline (PBS) with penicillin (1000 IU) and streptomycin $(1000 \mu \mathrm{g})$ at $2 \times 10^{7} / \mathrm{ml}$ (stock solution). According to the manufacturer, the oocysts were shed 14 days prior to delivery to the institute. The oocyst viability was assessed to be $82 \%$ via 4',6-diamidino-2-phenylindole/propidium iodide (DAPI/PI) stained oocysts in wet mounts immediately prior to inoculation of the first assay plate [33,34]. Oocyst morphology appeared normal, with a very low percentage (5\%) of 'ghost' oocysts (oocysts with no internal content). Oocysts were approximately 3 months-old when the first assay was conducted with all assays conducted within 10 days. Oocysts for inoculation of the plates were taken directly from the stock solution and prior to performing the assays, the oocyst concentration was determined by diluting $10 \mu \mathrm{l}$ stock solution with $990 \mu \mathrm{l}$ PBS and counting three repeats after staining with Crypt-a-Glo (Waterborne Inc, New Orleans, LA, USA).

\section{HCT-8 cell culture}

Human colon adenocarcinoma (HCT-8) cells (European collection of authenticated cell cultures (ECACC), Salisbury, UK) were cultured in maintenance medium (RPMI1640, Biowest, Nuaillé, France) supplemented with horse serum $(5 \% \mathrm{v} / \mathrm{v})$, foetal bovine serum $(\mathrm{FBS})(5 \% \mathrm{v} / \mathrm{v}), 1$ $\mathrm{mM}$ sodium pyruvate and an antibiotic/antimycotic solution (penicillin $(100 \mathrm{U} / \mathrm{ml})$, streptomycin $(100 \mu \mathrm{g} / \mathrm{ml})$ and amphotericin B $(0.25 \mu \mathrm{g} / \mathrm{ml})$ ) (all Sigma-Aldrich, St. Louis, MO, USA). Cell sub-cultivation was performed twice per week with trypsin/ethylenediaminetetraacetic acid (EDTA) (Sigma-Aldrich). Cells were incubated in 5\% $\mathrm{CO}_{2}$ at $37^{\circ} \mathrm{C}$.

\section{Parasite inoculation onto cell monolayer}

HCT-8 cells were seeded onto Nunclon ${ }^{\circledR}$ 96-well plates (Sigma-Aldrich) $\left(2 \times 10^{5}\right.$ cells/well $)$ and incubated in maintenance medium for $24 \mathrm{~h}$ until they reached confluence. Prior to infection of the cell monolayer, the oocysts were pre-treated as described by Slifko et al. [35]. Briefly, one part oocyst stock solution $\left(2 \times 10^{6}\right.$ oocysts $)$ was suspended in 1 part bleach solution, and 8 parts MilliQ water $(1107.2 \mathrm{ml}$ MilliQ water, $138.4 \mu \mathrm{l}$ oocyst suspension and $138.4 \mu \mathrm{l} 5.25 \%$ sodium hypochlorite solution) for $10 \mathrm{~min}$. The suspension was subsequently centrifuged at $4000 \times g$ for $4 \mathrm{~min}$ at $4{ }^{\circ} \mathrm{C}$ and the supernatant aspirated. The oocysts were then washed in $14 \mathrm{ml} \mathrm{Mil-}$ liQ water and centrifuged again $\left(4000 \times g, 4 \mathrm{~min}, 4{ }^{\circ} \mathrm{C}\right)$, aspirated down to $200 \mu \mathrm{l}$ and re-suspended in $1.8 \mathrm{ml}$ maintenance medium pre-warmed to $37^{\circ} \mathrm{C}$ to achieve a concentration of $10^{6}$ oocysts $/ \mathrm{ml}$. The oocyst suspension was vortexed $(10 \mathrm{~s})$ and $100 \mu \mathrm{l}(100,000$ oocysts) was subsequently diluted 10 -fold to achieve 6 suspensions $\left(10^{5}, 10^{4}, 10^{3}, 10^{2}, 10^{1}\right.$ and 1 oocysts $\left./ 100 \mu \mathrm{l}\right)$. Of each 
suspension, $100 \mu \mathrm{l}$ was inoculated onto the cell monolayers ( $\times 5$ repeats of each suspension) with a multi-channel pipette and incubated for $4 \mathrm{~h}\left(37^{\circ} \mathrm{C}, 5 \% \mathrm{CO}_{2}\right)$. Maintenance medium was added to 5 blank wells with cell monolayers to control for potential oocyst contamination and inactivated oocysts in five replicates $\left(5 \times 10^{5}\right)$ (incubated at $70^{\circ} \mathrm{C}, 30 \mathrm{~min}$ ) as a control for the washing steps. After incubation the oocysts suspensions and maintenance media were aspirated and washed once for $5 \min \left(37^{\circ} \mathrm{C}\right.$ PBS) and $100 \mu \mathrm{l}$ fresh maintenance medium (1\% dimethyl sulfoxide, DMSO) was added to the monolayers. Maintenance medium $(100 \mu \mathrm{l}, 1 \%$ DMSO) was added to 2 wells containing no cells as a further control for contamination. Plates were subsequently incubated for $44 \mathrm{~h}$. Oocyst inoculations were performed twice, on two separate plates, A and B. HCT-8 cells were on their 4th passage prior to use in the assays.

\section{Oocyst serial dilution}

Stock oocysts $\left(1 \mathrm{ml}, 2 \times 10^{7} / \mathrm{ml}\right)$ were centrifuged at $4000 \times g$ for $5 \mathrm{~min}$ and the supernatant aspirated down to $200 \mu \mathrm{l}$ to yield an oocyst suspension of $2 \times 10^{7} / 200 \mu \mathrm{l}$. This suspension was vortexed (10 s) and diluted 10-fold (MilliQ water) $\times 6$ to achieve 7 suspensions: $10^{6}, 10^{5}, 10^{4}$, $10^{3}, 10^{2}, 10^{1}$ and 1 oocysts $/ 10 \mu \mathrm{l}$ in $1.5 \mathrm{ml}$ Eppendorf tubes. This was performed twice, yielding two separate serial dilutions of oocyst suspensions. For each dilution, a $1.5 \mathrm{ml}$ Eppendorf tube containing $200 \mu \mathrm{l}$ of MillQ was prepared in parallel as a negative control.

\section{DNA extraction}

After incubation for $44 \mathrm{~h}$, the maintenance medium was aspirated and a water-soluble tetrazolium (WST)-1 assay (Roche, Basel, Switzerland) performed to assess cell viability as per manufacturer's instructions. Briefly, $100 \mu \mathrm{l} 10 \% \mathrm{v} / \mathrm{v}$ WST-1 solution in maintenance medium was added to each well and plates incubated for $30 \mathrm{~min}$ $\left(37{ }^{\circ} \mathrm{C}, 5 \% \mathrm{CO}_{2}\right)$. Subsequently, optical density (OD) was read at $450 \mathrm{~nm}$. Cells were then washed $3 \times 5 \mathrm{~min}(100$ $\left.\mu \mathrm{l}, 37{ }^{\circ} \mathrm{C} \mathrm{PBS}\right)$ prior to cell lysis. Proteinase $\mathrm{K}(20 \mu \mathrm{l})$ and animal tissue lysis (ATL) buffer $(180 \mu \mathrm{l})$ (Qiagen, Hilden, Germany) were added to each well and incubated $\left(56{ }^{\circ} \mathrm{C}\right)$ for $90 \mathrm{~min}$. All well contents were aspirated into $1.5 \mathrm{ml}$ Eppendorf tubes. For pure oocyst suspensions, Proteinase $\mathrm{K}$ and ATL buffer were added directly into $1.5 \mathrm{ml}$ Eppendorf tubes containing $10 \mu \mathrm{l}$ oocyst suspension. DNA was extracted using QiaCube (DNeasy ${ }^{\circledR}$ Blood \& Tissue Kit, Qiagen) with the tissues and rodent tails protocol (elution volume $200 \mu \mathrm{l}$ ). DNA template from $10^{6}$ of the pure oocyst suspension was then diluted 10-fold (6 dilutions corresponding to equivalent pure oocyst suspension dilutions) with $\mathrm{dH}_{2} \mathrm{O}$ (nuclease-free water-Integrated DNA Technologies, Coralville, IA, USA).

\section{qPCR assay}

Real-time PCR was carried out using the $18 S$ primers described previously by Morgan et al. [36] (Cryp18S_Frt 5'-AGT GAC AAG AAA TAA CAA TAC AGG-3' and Cryp18S_Rrt 5'-CCT GCT TTA AGC ACT CTA ATT TTC-3) with the hydrolysis probe containing an internal $\mathrm{ZEN}^{\mathrm{TM}}$ quencher to lower background and increase signal detection (5'-/56-FAM/ACC AGA CTT/ZEN/GCC CTC C/3IABkFQ/-3). Probe design was from Keegan et al. [23], and was based on a conserved eukaryotic sequence first used by Amman et al. [37] both supplied by Integrated DNA Technologies (Coralville). PCR reactions were carried out in a total volume of $25 \mu \mathrm{l}$ comprising of $3 \mu \mathrm{l}$ forward and reverse primers, $0.6 \mu \mathrm{l}$ probe, 12.5 $\mu \mathrm{l} 2 \times$ Brilliant III Fast MasterMix (Agilent Technologies, Santa Clara, CA, USA), $5.4 \mu \mathrm{d} \mathrm{d}_{2} \mathrm{O}$ (nuclease-free water, Integrated DNA Technologies) and $0.5 \mu \mathrm{l}$ DNA template. Two technical repeats were run for each sample in all assays. Six assays were run on the BIORAD CFX real-time instrument (BioRad, Hercules, CA, USA) using 96-well clear bottomed qPCR plates (BioRad). Six different qPCR runs were prepared: (i) and (ii) oocyst monolayer inoculations (cell monolayer plate A on qPCR Plate (i), and cell monolayer plate B on qPCR Plate (ii); (iii) stock oocyst serial dilution A and B; (iv) oocyst stock dilution $\mathrm{A}$ and $\mathrm{B}$ with their respective DNA template dilutions; and (v) and (vi) 3 biological repeats from the monolayer inoculations at the four highest inoculation concentrations $\left(10^{5}, 10^{4}, 10^{3}\right.$ and $\left.10^{2}\right)$, oocyst stock dilutions at the 5 highest suspension concentrations $\left(10^{6}, 10^{5}\right.$, $10^{4}, 10^{3}$ and $10^{2}$ ) and their respective DNA template dilutions. It was subsequently determined that differences between cell culture incubated oocysts and equivalent DNA template dilutions of the highest concentration would be valuable. DNA template from a separate oocyst titration study (cell monolayer plate C, $5 \times 10^{4}-50$, 2 biological repeats per oocyst concentration) were run on Plate (vii) alongside $5 \times 10^{4}$ ten-fold diluted template $(\times 10-\times 1000$, one dilution series for each biological repeat) (Fig. 1). This later titration study (cell monolayer plate C) was conducted approximately 1 month after the previous assays. However, as the comparison is between cell culture template and serially diluted template from the same oocysts this was not deemed to be a major limitation. Monolayer inoculation plate A was run with stock oocyst dilution series A and monolayer inoculation plate B with oocyst dilution series B. Each DNA template was run in duplicate on each plate. Cycling conditions were as follows: $95^{\circ} \mathrm{C}$ for $2 \mathrm{~min}$, followed by 44 cycles $\left(95^{\circ} \mathrm{C}\right.$ for $10 \mathrm{~s}, 58^{\circ} \mathrm{C}$ for $10 \mathrm{~s}, 72{ }^{\circ} \mathrm{C}$ for $20 \mathrm{~s}$ ) on a C1000 Touch thermal cycler (BioRad). BioRad CFX Manager Software [38] was used to analyse the amplification curves. Quantification cycle was set at the beginning of the log-linear phase 
of the amplification plot where the variation of Cq-values between technical repeats were minimal. Non-template controls (NTC) were included on each qPCR plate with $\mathrm{Cq} \geq 40$ considered negative [39].

\section{Flow cytometry}

A 10 -fold dilution of oocysts $\left(5 \times 10^{4}-0.5\right.$; 5 replicates for each suspension) in maintenance medium $(100 \mu \mathrm{l})$ was seeded onto a 96-well plate with a multi-channel pipette without cells and inter-well variation assessed by flow cytometry with the NovoCyte NovoSampler (Acea Biosciences Inc, Santa Clara, CA, USA), sample volume $60 \mu \mathrm{l}$, threshold set to Forward scatter $-\mathrm{H}(\mathrm{FS}-\mathrm{H})<300$. Output was analysed with NovoExpress software and samples were gated based on blank control background readings to only include oocyst counts.

\section{Qubit $^{\mathrm{TM}}$ DNA quantification}

Qubit $^{\mathrm{TM}}$ DNA quantification was performed with Qubit ${ }^{\mathrm{TM}}$ $1 \times$ double stranded DNA (dsDNA) HS Assay Kit (Thermo Fisher Scientific, Waltham, MA, USA). Ten microlitres of DNA template from each biological repeat from cell inoculation plate $C\left(5 \times 10^{4}-500\right)$ and equivalent concentrations of freely suspended oocysts were added to $190 \mu \mathrm{l}$ Qubit $^{\mathrm{TM}} 1 \times$ dsDNA HS Working Solution. Samples were vortexed (5 s) and centrifuged (5 s) prior to being analysed on an Invitrogen Qubit 4 fluorometer (Thermo Fisher Scientific). DNA content was recorded as $\mathrm{ng} / \mu \mathrm{l}$ calibrated with Qubit ${ }^{\mathrm{TM}} 1 \times$ dsDNA HS Standard \#1 and Qubit ${ }^{\mathrm{TM}} 1 \times$ dsDNA HS Standard \#2 included in the kit.

\section{Statistics}

Differences between Cq-values on the same plate were assessed via linear regression. Differences were considered significant if $P \leq 0.05$. All data was analysed in $\mathrm{R}$ [40]. Standard curves were produced in BIORAD CFX Manager v3.1 [38].

\section{Results}

Oocyst monolayer inoculations: Plates (i) and (ii)

A substantial loss in cell viability was observed in all wells inoculated with $10^{5}$ oocysts for inoculation plate A (50 \pm $11.4 \%$ compared with blank wells). For plate B, $3 / 5$ wells exhibited $\mathrm{OD}_{450}$ values $>75 \%(82.4 \pm 6.5 \%)$, a threshold previously considered not to constitute toxicity in pharmaceutical screenings [11]. The remaining two wells had $\mathrm{OD}_{450}$ values 66.9 and $9.1 \%$ when compared to the blank controls. Laboratory error resulted in marked pipette damage on the cell monolayer to the latter and was thus excluded from all subsequent analyses.
Average Cq-values across biological repeats for Plate (i) were $28.76 \pm 0.81,29.69 \pm 0.38,33.45 \pm 1.09,36.5 \pm$ $0.66,41.28 \pm 2.54$ and $42.66 \pm 1.19$ for oocyst inoculates of $10^{5}$ to $1 /$ well, respectively $\left(R^{2}=0.899\right)$. Two technical repeats (well $4,10^{5}$ oocysts, and well 5,1 oocyst) were clear outliers due to experimental error and were removed from the analysis. For Plate (ii) Cq values were: $28.91 \pm 0.85,30.43 \pm 0.88,34.73 \pm 0.74$ and $37.39 \pm 0.6$ for oocyst inoculates $10^{5}$ to $10^{2}\left(R^{2}=0.901\right)$. Average Cq-values for one oocyst across biological repeats was $43.27 \pm 1.26$. For inoculates of 10 oocysts, amplification of DNA was observed in only one well for both technical repeats, $\mathrm{Cq}$ of $41.06 \pm 0.77$ for Plate (ii). Inactivated oocysts inoculated at $10^{5} /$ well indicated Cq-values across biological repeats of $36.34 \pm 0.56$ for Plate (i) and $37.39 \pm$ 0.72 for Plate (ii). Cq-values for inactivated oocysts were not significantly different from those obtained from 100 stock oocyst inoculate $(P=0.7$ and 0.99 for Plate (i) and (ii), respectively) but were significantly different for all other concentrations (Additional file 1: Table S1, Additional file 2: Table S2).

\section{Stock oocyst dilutions: Plate (iii)}

For 10-fold dilutions of pure stock oocysts, average Cqvalues across two technical repeats were $29.45 \pm 0.42$, $31.34 \pm 31.34$ and $34.61 \pm 0.28$ for $10^{6}, 10^{5}$ and $10^{4}$ oocysts, respectively for serial dilution $\mathrm{A}\left(R^{2}=0.971\right)$. For $10^{3}$ oocysts, one technical repeat failed to amplify any DNA with a Cq-value of 38 for the other. For serial dilution $\mathrm{B}, \mathrm{Cq}$-values were $28.74 \pm 0.42,30.29 \pm 0.16,33.86$ \pm 0.22 and $37.84 \pm 0.75$ for $10^{6}, 10^{5}, 10^{4}$ and $10^{3}$ oocysts, respectively. No signal was detected for DNA from $10^{2}$, $10^{1}$ and 1 for either dilution series $\left(R^{2}=0.968\right)$. No signal was observed for MilliQ water negative controls, as expected (Additional file 3: Table S3).

\section{Stock oocyst dilutions and DNA template dilutions: Plate (iv)}

Ten-fold dilutions of stock oocysts yielded Cq-values of $28.9 \pm 0.8,31.09 \pm 0.25,34.24 \pm 0.03,38.17 \pm 0.75$ and $43.34 \pm 0.5$ for $10^{6}, 10^{5}, 10^{4}, 10^{3}$ and $10^{2}$ oocysts, respectively in serial dilution $\mathrm{A}\left(R^{2}=0.967\right)$ and $27.62 \pm 0.67$, $30.35 \pm 0.15,33.64 \pm 0.24,37.95 \pm 0.56$ and $40.82 \pm$ 0.34 for $10^{6}, 10^{5}, 10^{4}, 10^{3}$ and $10^{2}$ in serial dilution $\mathrm{B}\left(R^{2}\right.$ $=0.956$ ). Similar reductions in Cq-values were observed for corresponding dilutions of these templates: $31.04 \pm$ $0.35,34.09 \pm 0.53,38.11$ (one technical repeat failed to amplify DNA) and $40.82 \pm 0.34$ for $\times 10, \times 10^{2}, \times 10^{3}$ and $\times 10^{4}$ dilutions, dilution $\mathrm{A}\left(R^{2}=0.987\right)$. DNA template dilutions of serial dilution B gave Cq-values of $30.52 \pm$ $0.17,35.11 \pm 0.04,38.19 \pm 0.08$ and 41.37 (one technical repeat failed to amplify DNA) for $\times 10, \times 10^{2}, \times 10^{3}$ and $\times 10^{4}$ dilutions $\left(R^{2}=0.951\right)$. No DNA was amplified 

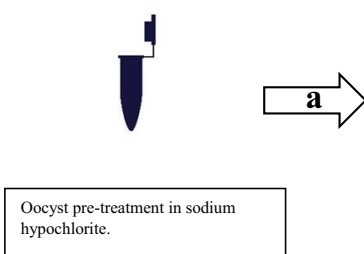

Oocyst pre-ticin
hypochlorite

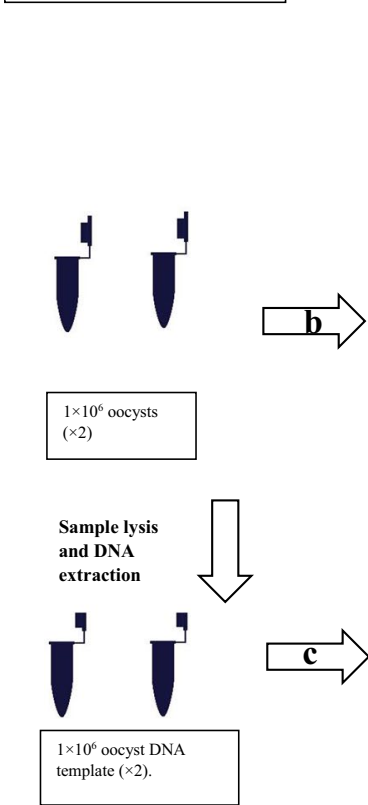

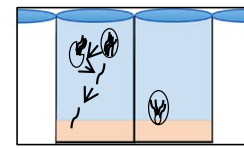
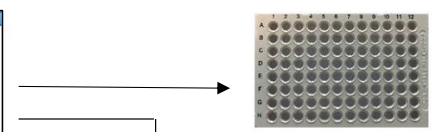

00008

Quantitative PCR run (i) and (ii): Two technical repeats for each wel (biological repeat).

B

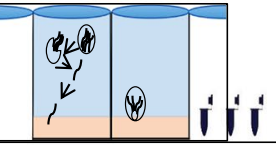

A) Oocyst serial dilution inoculated into HCT-8 monolayer on 96well plates (cell monolayer plate A\&B). $10^{5}-1$ oocyst/well (5

B) Oocyst serial dilution inoculated into HCT-8 monolayer on 96well plates (cell monolayer plate C). $5 \times 10^{4}-5 \times 10^{1}(2$ replicates (biological repeat) and $\times 10-\times 1000$ serial dilution of each $5 \times 10^{4}$ replicate.

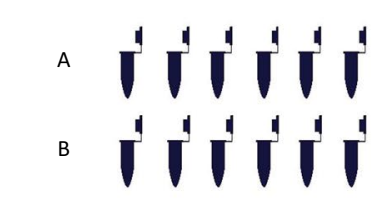

10-fold oocyst serial dilution yielding $1 \times 10^{6}-1$ oocyst $(\times 2)$ Dilution series A and B.
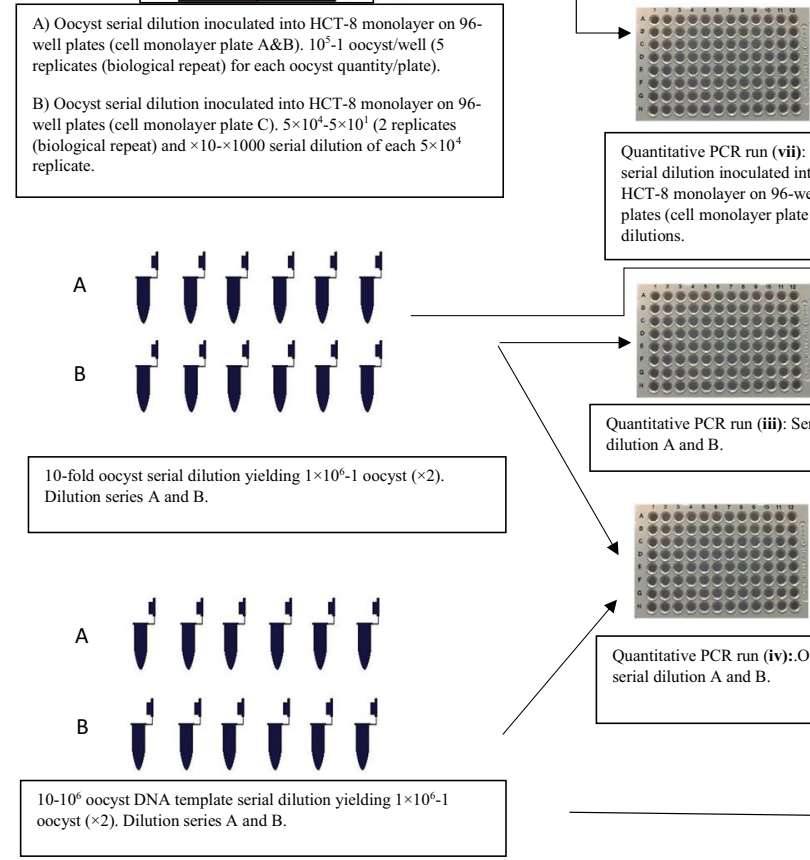

Quantitative PCR run (vii): Oocyst serial dilution inoculated into
HCT-8 monolayer on 96 -well plates (cell monolayer plate $\mathrm{C}$ ) and

dilutions.

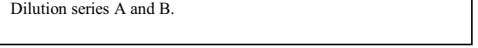

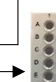

:-8 800000000000 800080000908

uantitative PCR run (iii): Serial dilution $\mathrm{A}$ and $\mathrm{B}$
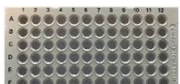

00090909009

Ountitative PCR run (iv): Oocyst serial dilution $\mathrm{A}$ and $\mathrm{B}$

Fig. 1 Schematic diagram for each of the three methods for producing standard DNA templates. Ten-fold dilutions of Cryptosporidium parvum oocysts inoculated onto cell culture (a), ten-fold dilutions of pure oocyst suspensions (b) and ten- $10^{6}$ dilutions of $10^{6} \mathrm{C}$. parvum oocyst extracted DNA template (c). Colour illustration in figure adapted from [12] and used with permission

at the $\times 10^{5}$ or $\times 10^{6}$ dilutions. No signal was observed for the MilliQ water negative control (Additional file 4: Table S4).

\section{Oocyst monolayer inoculations, stock oocyst dilutions and DNA template dilutions: Plates (v) and (vi)}

Average Cq-values across biological repeats were $30.76 \pm$ $0.5,31.79 \pm 0.48$ and $36.18 \pm 0.85$ for $10^{5}, 10^{4}$ and $10^{3}$ oocyst inoculates, respectively for Plate (v). With Cqvalues from all biological and technical repeats pooled, change in $\mathrm{Cq}(\triangle \mathrm{Cq})$ was $1.03\left(10^{5}-10^{4}, P=0.017\right), 4.33$ $\left(10^{4}-10^{3}, P<0.0001\right)$ and $4.91\left(10^{3}-10^{2}, P=0.002\right)$ (Table 1, Figs. 2, 3a), with a linearity of $R^{2}=0.901$ and amplification efficiency of $122.8 \%$ (Fig. 4a), but 100 oocysts per well inoculates failed to generate a positive signal across both technical repeats for any well. The average $\Delta$ Cq-value between concentrations was $2.78 \pm$ 1.37. The blank controls produced signal for two technical repeats in separate wells $(43.93 \pm 0.51)$ with one reaction containing inactivated oocysts producing a signal
$(37.33 \pm 1.00)$ in both repeats. The highest four 10 -fold stock oocyst dilutions from $10^{6}$ produced Cq-values of $28.65 \pm 0.65,31.42 \pm 0.11,34.35 \pm 0.19$ and $37.3 \pm$ 0.2 , with 100 oocysts remaining negative. Average $\Delta \mathrm{Cq}$ values for 10-fold dilutions were $2.89 \pm 0.08\left(10^{6}-10^{5}, P\right.$ $=0.051), 2.93\left(10^{5}-10^{4}, P=0.005\right), 2.96\left(10^{4}-10^{3}, P=\right.$ $0.008)\left(R^{2}=0.988\right.$, amplification efficiency of $121.9 \%$; Table 2, Figs. 2, 3b, 4b). A similar association was found with DNA template dilutions, 32 and 34.90 , for the $\times 10$ and $\times 10^{2}$ dilutions, respectively, with an average $\Delta \mathrm{Cq}$ of $3.45 \pm 0.175\left(R^{2}=0.969\right.$, amplification efficiency of 121.9\%; Table 3, Figs. 2, 3c, 4c), with no significant difference between these and the stock oocyst dilutions in Plate (v). However, the $\times 10^{3}$ and $\times 10^{4}$ dilutions failed to produce signal. Significantly lower Cq-values were found for the same oocyst numbers grown in cell culture for $10^{5}$ in comparison to the equivalent template dilution $(P=0.028)$ but not the pure oocyst suspension $(P$ $=0.188$ ). For $10^{4}$ suspensions and the diluted template DNA equivalent, cell cultured oocysts had significantly 
lower Cq-values than both the stock dilution and template DNA dilution $(P=0.009$ and 0.003 for stock and template dilutions, respectively). For $10^{3}$ oocysts, no difference was found between cell cultured oocysts and pure oocyst dilutions $(P=0.132)$ and no signal was observed in the equivalent diluted template. No signal was observed for $10^{2}$ stock oocysts nor the respective diluted and the three technical repeats failed to amplify in the cell culture wells. No significant differences were observed between stock oocyst dilutions and the templates at the highest two template concentrations (i.e. the two concentrations where DNA signal was produced across all three DNA standard types).

For Plate (vi), the average Cq-values across biological repeats in cell cultured oocysts were $29.21 \pm 0.50,30.66$ $\pm 0.30,35.16 \pm 0.90$ and $37.15 \pm 0.86$ for $10^{5}-10^{2}$ oocyst inoculates. With Cq-values from all biological and technical repeats pooled, $\Delta C$-values were $1.44\left(1 \times 10^{5}-1 \times\right.$ $\left.10^{4}, P<0.001\right), 4.5\left(10^{4}-10^{3}, P<0.0001\right)$ and $2\left(10^{3}-10^{2}\right.$, $P=0.008)$. The average $\Delta$ Cq was $2.65 \pm 1.33\left(R^{2}=0.910\right.$, amplification efficiency of $125.5 \%$; Table 4, Figs. 5, 6a, 7a). For inactivated oocysts, the average Cq-value across biological repeats was $37.49 \pm 0.35$. Serial stock oocyst dilution values were $27.53 \pm 0.4,29.72 \pm 0.21,36.24 \pm$ 0.46 and $40.95 \pm 0.23$ for $10^{6}-10^{2}$ oocyst inoculates. $\Delta$ Cq-values were $2.19\left(10^{6}-10^{5}, P=0.04\right), 2.85\left(10^{5}-10^{4}\right.$,
$P=0.024), 3.7\left(10^{4}-10^{3}, P=0.018\right)$ and $4.71\left(10^{3}-10^{2}\right.$, $P=0.01)$. The average $\Delta$ Cq was $2.9 \pm 0.62\left(R^{2}=0.974\right.$, amplification efficiency of $99.5 \%$; Table 5, Figs. 5, 6, 7b). For the template DNA dilutions the average Cq-values were $30.99 \pm 0.03,34.43 \pm 0.15$ and $37.39 \pm 0.02\left(\times 10^{1}\right.$, $\times 10^{1}$ and $\times 10^{2}$ dilutions, respectively; only one technical repeat was amplified for the $\times 10^{3}$ dilution, $\mathrm{Cq}=$ 41.1). $\triangle \mathrm{Cq}$-values for the template DNA dilutions were 3.45 and $2.94\left(\times 10-\times 10^{2}, P=0.002\right.$; and $\times 10^{2}-\times 10^{3}, P$ $=0.0026$ dilutions, respectively). The average $\Delta \mathrm{Cq}$ was $3.37 \pm 0.31\left(R^{2}=0.997\right.$, amplification efficiency of $101 \%$; Table 6, Figs. 5, 6, 7c). One hundred thousand oocysts in cell culture did not produce significantly lower Cq-values than diluted stock oocysts, but they did for the equivalent DNA template $(P=0.007)$; for $10^{4}$, both stock dilution and equivalent template dilutions having significantly higher $\mathrm{Cq}$-values than cell culture $(P=0.0004$ and $<$ 0.0001 , stock and template dilutions, respectively) and for $10^{3}(P=0.003$ and 0.001 , stock and DNA template dilutions, respectively). One hundred oocysts in cell culture produced significantly lower Cq-values compared to stock oocyst dilutions $(P=0.003)$ and the equivalent template dilutions $(P=0.001)$. No significant differences were found between the stock oocyst dilutions and their equivalent DNA template dilution with the exception of $10^{4}$, where the Cq-value of the template was significantly

Table 1 Cq values of quantitative PCR Plate (v)

\begin{tabular}{|c|c|c|c|c|c|c|c|}
\hline \multirow[t]{2}{*}{ Oocyst inoculate } & & \multicolumn{2}{|l|}{ Well 1} & \multicolumn{2}{|l|}{ Well 2} & \multicolumn{2}{|l|}{ Well 3} \\
\hline & & TR1 & TR2 & TR1 & TR2 & TR1 & TR2 \\
\hline 100,000 & & 31.75 & 31.11 & 30.72 & 30.55 & 30.42 & 30 \\
\hline \multirow[t]{2}{*}{ Mean $\pm S D$} & TR & $31.43 \pm 0.32$ & & $30.64 \pm 0.09$ & & $30.21 \pm 0.21$ & \\
\hline & $\mathrm{BR}$ & $30.76 \pm 0.50$ & & & & & \\
\hline 10,000 & & 31.48 & 31.66 & 31.15 & 31.54 & 31.85 & 37.07 \\
\hline \multirow[t]{2}{*}{ Mean $\pm S D$} & TR & $31.57 \pm 0.09$ & & $31.35 \pm 0.19$ & & $32.46 \pm 0.19$ & \\
\hline & BR & $31.79 \pm 0.48$ & & & & & \\
\hline 1000 & & na & 37.59 & 35.96 & 35.64 & 36.14 & 35.57 \\
\hline \multirow[t]{2}{*}{ Mean \pm SD } & $\mathrm{TR}$ & na & & $35.8 \pm 0.16$ & & $35.86 \pm 0.29$ & \\
\hline & $\mathrm{BR}$ & $36.18 \pm 0.85$ & & & & & \\
\hline 100 & & 39.24 & na & 38.34 & na & na & 39.7 \\
\hline \multirow[t]{2}{*}{ Mean $\pm S D$} & TR & na & & na & & na & \\
\hline & $\mathrm{BR}$ & na & & & & & \\
\hline Blank wells & & na & 43.42 & na & na & 44.44 & na \\
\hline \multirow[t]{2}{*}{ Mean $\pm S D$} & $\mathrm{TR}$ & na & & & & & \\
\hline & $\mathrm{BR}$ & $43.92 \pm 0.51$ & & & & & \\
\hline Inactivated oocysts & & na & na & 38.33 & 36.32 & na & na \\
\hline \multirow[t]{2}{*}{ Mean \pm SD } & TR & na & & $37.33 \pm 1.00$ & & na & na \\
\hline & $B R$ & $37.33 \pm 1.00$ & & & & & \\
\hline
\end{tabular}

Notes: Cryptosporidium parvum oocysts inoculated onto HCT-8 cell monolayer plate A. Two technical repeats for each well (biological repeat). Baseline threshold 11.89 RFU 


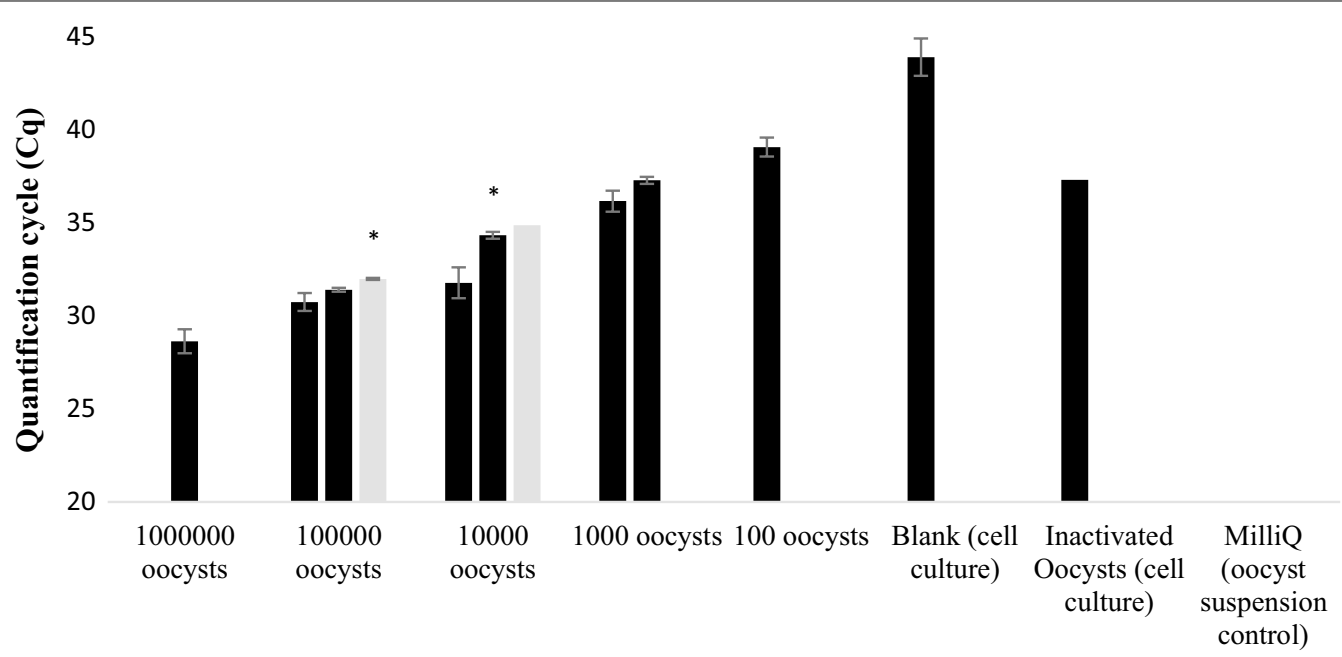

Oocyst quantity/inoculate/equivalent template dilution

- Cell culture - Pure oocyst suspension Oocyst suspension template dilution

Fig. 2 Average differences in Cq-values for quantitative PCR Plate (v) between Cryptosporidium parvum oocysts inoculated onto HCT-8 monolayer plate A, pure oocyst serial dilution A and equivalent template dilution A. Error bars represent the standard deviation of the mean (SD) from 3 biological repeats for cell culture data and SD of two technical repeats for the pure oocyst serial dilution and equivalent template dilution data. Asterisks indicate significantly increased Cq signal $(P<0.05)$ compared to cell culture derived values

higher than that of the stock dilution $(P=.0 .0013)$. Inactivated oocyst Cq-values were not significantly different to values obtained from $10^{2}$ oocyst inoculate in cell culture $(P=0.464)$.

\section{Oocyst monolayer inoculations and DNA template dilutions: Plate (vii)}

Cq-values across biological repeats in cell cultured oocysts were $30.07 \pm 0.9,30.91 \pm 0.24,34.84 \pm 0.52$ and $37.81 \pm 0.89$ for $5 \times 10^{4}-50$ oocyst inoculates $\left(R^{2}=9.06\right.$, amplification efficiency of 133.5\%; Fig. 8a). For the 10-fold dilution of the $5 \times 10^{4}$ cell culture standards, Cq-values (averaged across both dilution series) were $32.93 \pm 0.68$, $36.15 \pm 1.07$ and $39.89 \pm 0.36$ for $\times 10-\times 1000$ cell cultured DNA template dilutions, respectively $\left(R^{2}=0.952\right.$, amplification efficiency of $102.3 \%$; Fig. 8b). Significantly lower Cq-values were obtained in cell cultured oocysts at $5 \times 10^{3}$ and 50 compared to the equivalent diluted template ( $P=0.003$ and 0.01 , respectively) (Fig. 9).

\section{Flow cytometry}

Flow cytometric analysis revealed relatively low variation for oocyst inoculates seeded at high concentration suspensions $\left( \pm 7.0 \%\right.$ and $7.2 \%$ for $5 \times 10^{4}$ and $5 \times$ $10^{3}$, respectively) but at lower seeding densities variation increased substantially $( \pm 31.63 \%, 22.2 \%, 16.73 \%$ and $45.7 \%$ for $5 \times 10^{2}, 5 \times 10^{1}, 5$ and 0.5 oocysts, respectively).

\section{Qubit $^{\mathrm{TM}}$ DNA quantification}

The average DNA concentration for cell cultured samples was $6.08 \pm 1.12,9.1 \pm 0.78$ and $10.08 \pm 0.56 \mathrm{ng} / \mu \mathrm{l}$ from $5 \times 10^{4}-500$ oocyst inoculates with $5 \times 10^{4}$ freely suspended oocysts averaging $0.045 \pm 0.005 \mathrm{ng} / \mu \mathrm{l}$. DNA content was too low in all lower concentrations of freely suspended oocysts for signal detection.

\section{Discussion}

This study clearly demonstrates important differences in the results generated between cell-culture incubated oocysts, pure oocyst dilutions and their respective DNA template equivalents when used as standards for qPCR. Their use as standards in experiments could influence the results if precise data are needed, as the results demonstrate important differences in linearity and $\Delta$ Cq between the methods. To the best of our knowledge, this is the first study to compare different protocols for preparing qPCR standards for C. parvum and their comparative results when calculating parasite content.

In plates (v) and (vi), cell culture Cq-values in many samples were significantly lower than values observed for stock oocyst dilutions and the equivalent template dilutions although this was not found uniformly across 


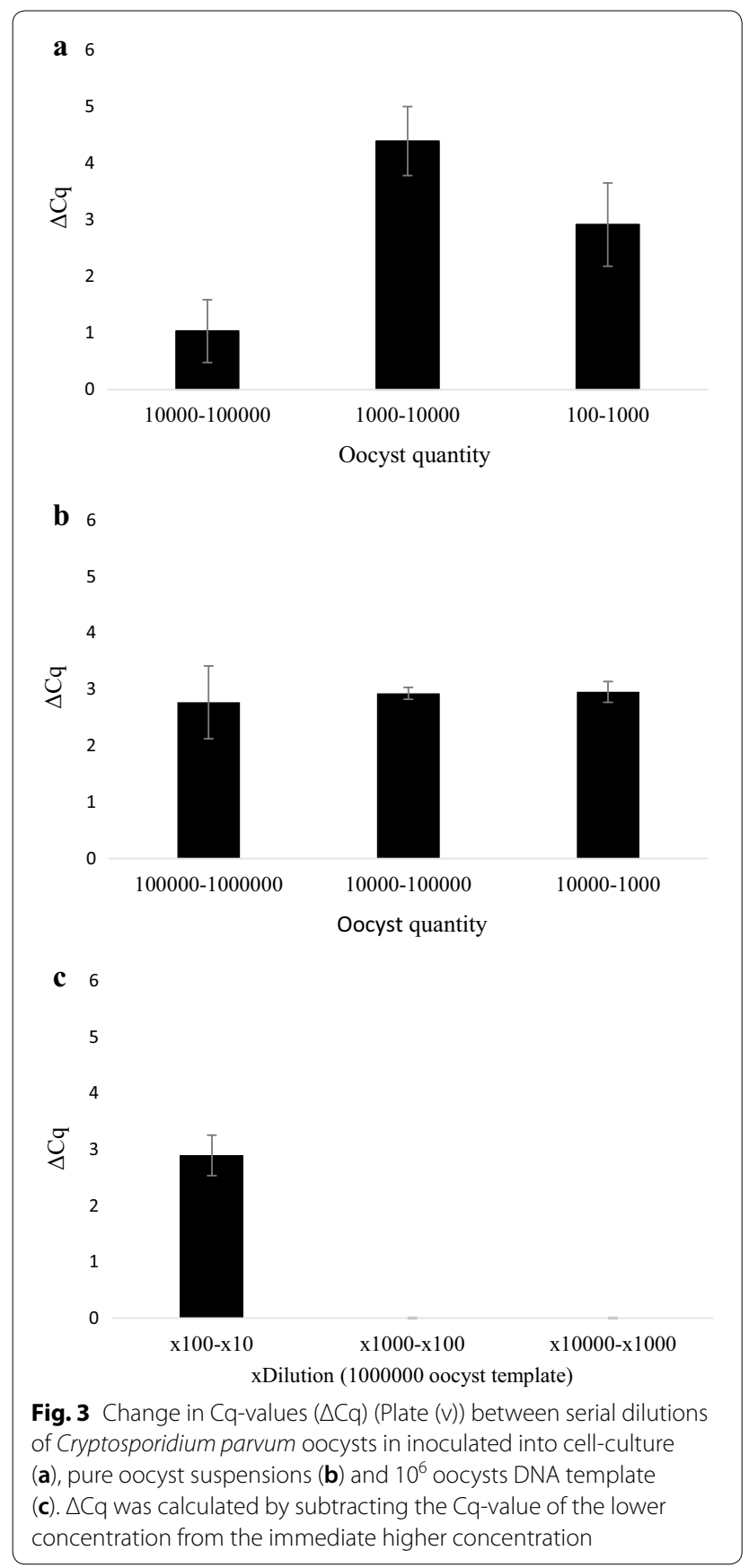

all oocyst concentrations. For $10^{5}$ both plates produced significantly lower Cq-values (i.e. indicating that more parasite DNA was present) in cell culture, compared to the diluted templates, but not for pure oocyst suspensions. For Plate (vi), all subsequent lower concentrations produced significantly lower Cq-values in cell culture compared to the stock oocyst and template dilutions, but for Plate (v), this was only the case for $10^{4}$ oocysts. No significant difference in Cq-values between stock
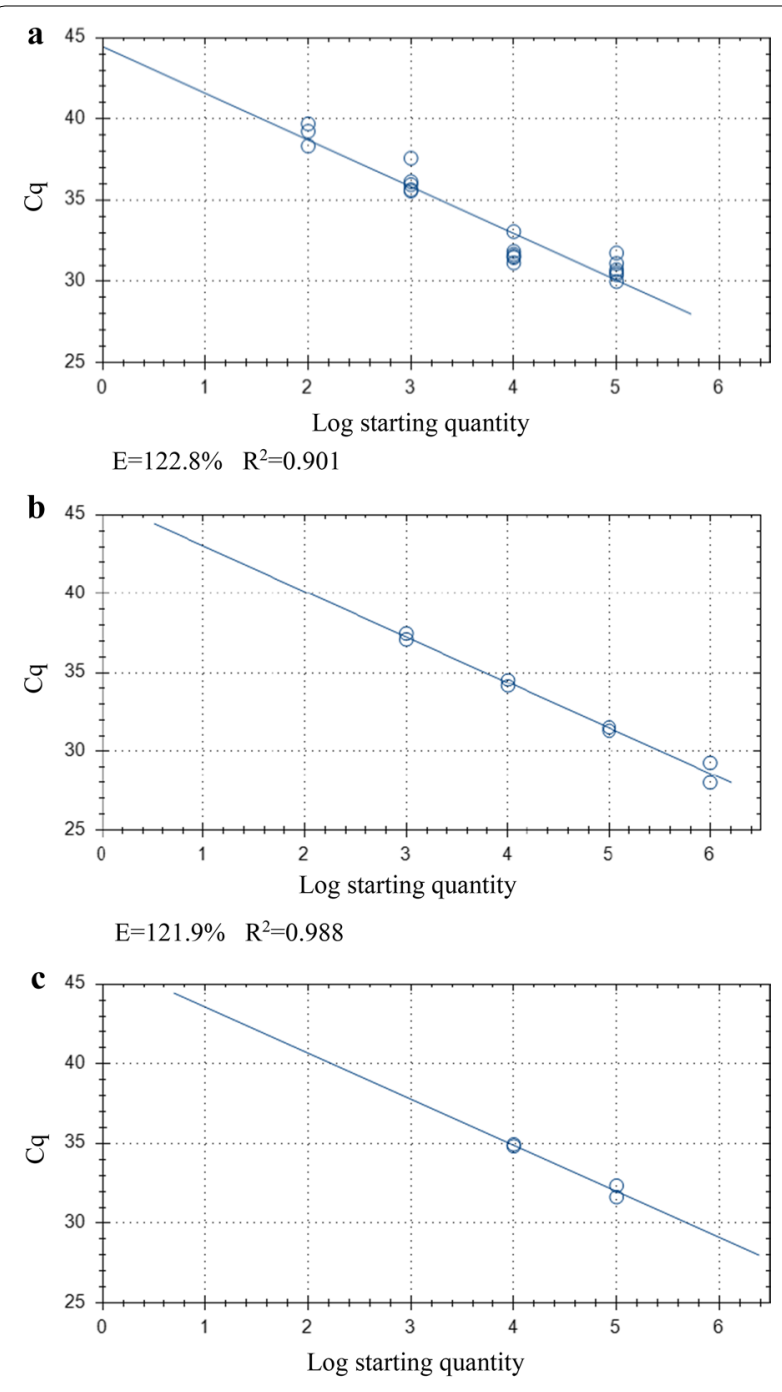

$\mathrm{E}=121.9 \% \quad \mathrm{R}^{2}=0.969$

Fig. 4 Standard curve generated for Plate (v) from Cryptosporidium parvum oocysts inoculated onto HCT-8 cell monolayer plate A $\left(10^{5}\right.$ $\left.10^{2}\right)(\mathbf{a})$, pure oocyst serial dilution $\mathrm{A}\left(10^{6}-10^{2}\right)(\mathbf{b})$ and equivalent template dilution A (c). Abbreviations: E, qPCR amplification efficiency; $R^{2}$, coefficient of variation

oocyst suspensions and cell culture were documented at $10^{3}$ oocysts. The lack of significantly higher quantities of DNA in the cell culture samples at $10^{5}$ oocysts may be attributable to the loss of cell viability in these wells although this is less likely to be a factor for Plate (vi). Cell stress as a result of a high oocyst inoculates is the likely cause of this loss of viability and a prospective study should assess any potential differences at lower oocyst inoculates. No DNA was amplified in any plates for stock oocyst dilutions and equivalent templates when there were $<100$ oocysts. 
Table 2 Cq values of quantitative PCR Plate (v)

\begin{tabular}{lll}
\hline Oocyst quantity & TR1 & TR2 \\
\hline $1,000,000$ & 29.29 & 28 \\
Mean TR \pm SD & $28.65 \pm 0.65$ & \\
100,000 & 31.52 & 31.31 \\
Mean TR \pm SD & $31.42 \pm 0.11$ & \\
10,000 & 34.16 & 34.53 \\
Mean TR \pm SD & $34.35 \pm 0.19$ & 37.49 \\
1000 & 37.11 & \\
Mean TR \pm SD & $37.3 \pm 0.20$ & na \\
100 & na & \\
Mean TR $\pm S D$ & na & na \\
MQ & na & \\
Mean TR $\pm S D$ & na & \\
\hline
\end{tabular}

Notes: Pure oocyst serial dilution A. Baseline threshold 11.89 RFU

Abbreviations: TR, technical repeat; SD, standard deviation; na, no DNA amplification

Table 3 Cq values of quantitative PCR Plate (v)

\begin{tabular}{lll}
\hline Template dilution & TR1 & TR2 \\
\hline$\times 10$ & 32.36 & 31.64 \\
Mean TR \pm SD & $32 \pm 0.36$ & \\
$\times 100$ & 34.84 & 34.95 \\
Mean TR \pm SD & $34.9 \pm 0.06$ & \\
$\times 1000$ & na & na \\
Mean TR \pm SD & na & na \\
$\times 10,000$ & na & \\
Mean TR \pm SD & na
\end{tabular}

Notes: DNA template dilution of $10^{6}$ oocyst suspension A. Baseline threshold 11.89 RFU

Abbreviations: TR, technical repeat; SD, standard deviation; na, no DNA amplification

The higher number of DNA copies obtained in cell culture inoculations compared with equivalent pure oocyst suspensions (or diluted DNA template of pure oocysts) is indicative of parasite growth. Once sporozoites have invaded the host cell, they undergo asexual and sexual multiplication and within 24 hours have produced meronts I [31] each containing 6-8 merozoites [13]. As each oocyst contains 4 sporozoites that will each individually perform asexual multiplication with subsequent later stages in the life-cycle reproducing sexually and although it is unclear which stages are specifically being amplified in cell culture [31], more DNA will be produced through growth.

For plates (v) and (vi) the standard deviation (SD) between technical repeats was $<0.5$ for all samples indicating high reproducibility [41]. However, these same templates, when analysed on plates (i), (ii), (iii) and (iv) exhibited variation $>0.5$ for some samples highlighting the influence of pipetting error during reaction mix or DNA template application. Supporting this, detection limits varied between plates especially for stock oocyst dilutions and their equivalent templates. Plate (iii) exhibited no detection of 100 stock oocysts and Plate (v) exhibited neither detection of 100 oocysts nor the $\times 10^{4}$ dilution despite these exact same templates amplifying DNA in Plate (iv). One hundred oocysts in cell culture on Plate (v) did not yield any Cq signal in one technical repeat of each well despite amplification being observed for the same templates in Plate (i) and Plate (ii), although one technical repeat for Plate (ii) failed to amplify for the $\times 10^{4}$ template dilution in Plate (ii). Laboratory error during pipetting the template onto the $\mathrm{qPCR}$ plate may explain the lack of detection in instances where signal is not produced in one technical repeat for each well (biological repeat). This could include insufficient or no template being placed in the qPCR plate well. In order to mitigate this in the future it would be optimal to increase the quantity of DNA template in the reaction. As it was imperative that the same templates were used multiple times to insure robust comparison between methods, we were only able to use $0.5 \mu \mathrm{l}$ in the present study. This may also explain the significantly higher Cq-value in the $10^{4}$ equivalent template dilution on Plate (vi) when all other concentrations were not statistically different. Although Cq-values varied between plates, overall, there was a consensus between the same templates analysed on different plates.

For subsequent studies, variation in seeding densities of oocysts and excessive variation between Cq-values of technical repeats, automated techniques should be considered. These have the potential to reduce variation due to experimental error caused by human operators. However, these are expensive and therefore unavailable in many laboratories. If automated techniques are unavailable, studies should consider increasing the number of repeats, both biological and technical, in order to mitigate the problems caused by high variation.

Mean Cq-values for inactivated oocysts were not significantly different from that of the 100 oocyst inoculates in cell culture in all four independent plates in which they were included, i.e. (i), (ii), (iii) and (iv), with all other concentrations exhibiting significantly higher or lower Cqvalues. This differs from the results obtained by Keegan et al. [23] where serially diluted inactivated oocysts $\left(10^{5}-1\right)$ were not detected in the qPCR assay, indicating the complete removal of unexcysted oocysts and oocyst debris from the monolayer. Washing steps were similar with $3 \times$ PBS washes per well in both studies although Keegan et al. [23] used 24-well plates and washed with $500 \mu \mathrm{l}$ PBS as opposed to 96-well plates with $100 \mu \mathrm{l}$ PBS 
Table 4 Cq values of Quantitative PCR Plate (vi)

\begin{tabular}{|c|c|c|c|c|c|c|c|}
\hline \multirow[t]{2}{*}{ Oocyst inoculate } & & \multicolumn{2}{|l|}{ Well 1} & \multicolumn{2}{|l|}{ Well 2} & \multicolumn{2}{|l|}{ Well 3} \\
\hline & & TR1 & TR2 & TR1 & TR2 & TR1 & TR2 \\
\hline 100,000 & & 30.25 & 29.52 & 28.29 & 28.83 & 28.4 & 28.98 \\
\hline \multirow[t]{2}{*}{ Mean \pm SD } & TR & $28.89 \pm 0.37$ & & $29.06 \pm 0.23$ & & $28.63 \pm 0.29$ & \\
\hline & BR & $29.21 \pm 0.50$ & & & & & \\
\hline 10,000 & & 30.24 & 30.90 & 30.29 & 30.39 & 30.95 & 31.19 \\
\hline \multirow[t]{2}{*}{ Mean \pm SD } & TR & $30.57 \pm 0.33$ & & $30.34 \pm 0.05$ & & $31.07 \pm 0.12$ & \\
\hline & $\mathrm{BR}$ & $30.66 \pm 0.30$ & & & & & \\
\hline 1000 & & 36.66 & 36.09 & 34.78 & 33.82 & 34.58 & 35.02 \\
\hline \multirow[t]{2}{*}{ Mean \pm SD } & TR & $36.38 \pm 0.29$ & & $34.3 \pm 0.48$ & & $34.8 \pm 0.22$ & \\
\hline & $\mathrm{BR}$ & $35.16 \pm 0.90$ & & & & & \\
\hline 100 & & 35.83 & 36.06 & 37.6 & 37.73 & 37.04 & 38.64 \\
\hline \multirow[t]{2}{*}{ Mean \pm SD } & TR & $35.95 \pm 0.12$ & & $37.67 \pm 0.07$ & & $37.84 \pm 0.80$ & \\
\hline & $\mathrm{BR}$ & $37.15 \pm 0.86$ & & & & & \\
\hline Blank wells & & na & 42.80 & 44 & 41.28 & 39.49 & na \\
\hline \multirow[t]{2}{*}{ Mean $\pm S D$} & TR & na & & $42.64 \pm 1.36$ & & na & \\
\hline & $\mathrm{BR}$ & $41.9 \pm 1.69$ & & & & & \\
\hline Inactivated oocysts & & 37.23 & 37.46 & 37.7 & 38.23 & 36.63 & 37.67 \\
\hline \multirow[t]{2}{*}{ Mean \pm SD } & TR & $37.35 \pm 0.12$ & & $37.97 \pm 0.27$ & & $37.15 \pm 0.52$ & \\
\hline & $\mathrm{BR}$ & $37.49 \pm 0.35$ & & & & & \\
\hline
\end{tabular}

Notes: C. parvum oocysts inoculated onto HCT-8 cell monolayer plate B. Two technical repeats for each well (biological repeat). Baseline threshold $19.88 \mathrm{RFU}$ Abbreviations: TR, technical repeat; BR, biological repeat; $\mathrm{SD}$, standard deviation; na, no DNA amplification

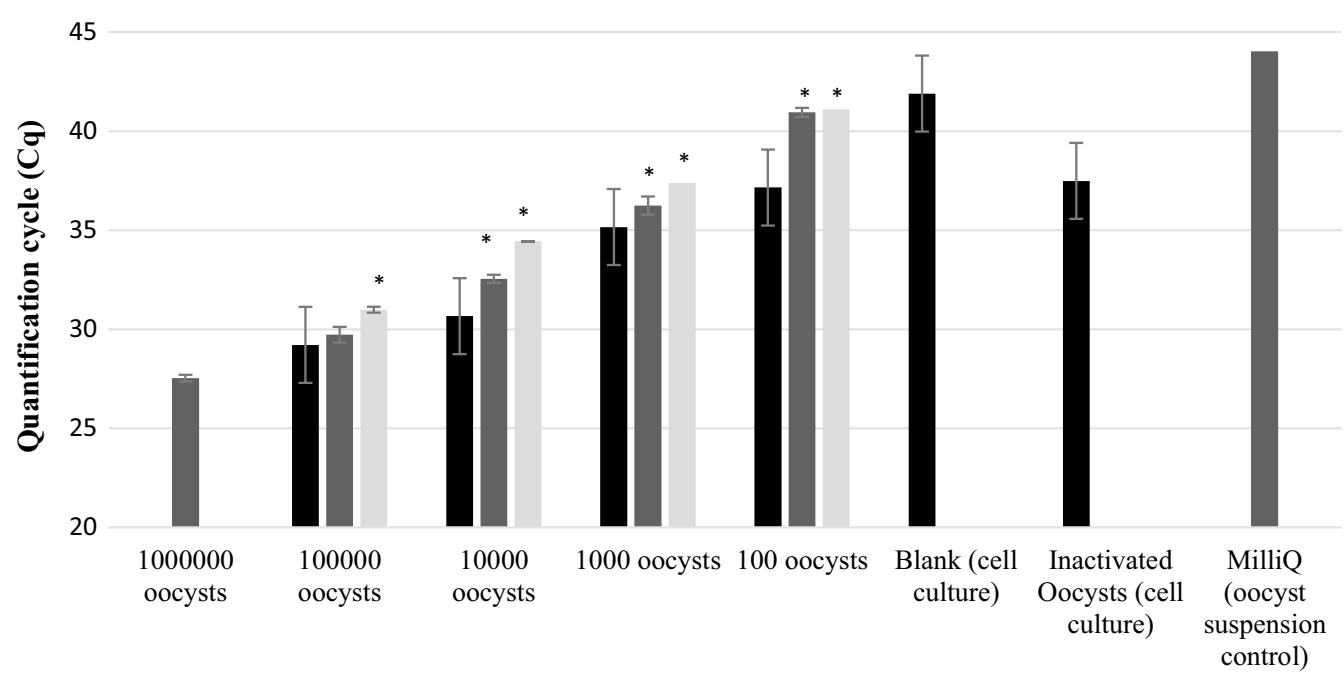

Oocyst quantity/inoculate/equivalent template dilution

- Cell culture $\quad$ Pure oocyst suspension Oocyst suspension template dilution

Fig. 5 Average differences in Cq-values for quantitative PCR Plate (v) between Cryptosporidium parvum oocysts inoculated onto HCT-8 monolayer plate B, pure oocyst serial dilution B and equivalent template dilution B. Error bars represent the standard deviation of the mean (SD) from 3 biological repeats for cell culture data and SD of two technical repeats of the pure oocyst serial dilution and equivalent template dilution data. Asterisks indicate significantly increased Cq signal $(P<0.05)$ compared to cell culture-derived values 


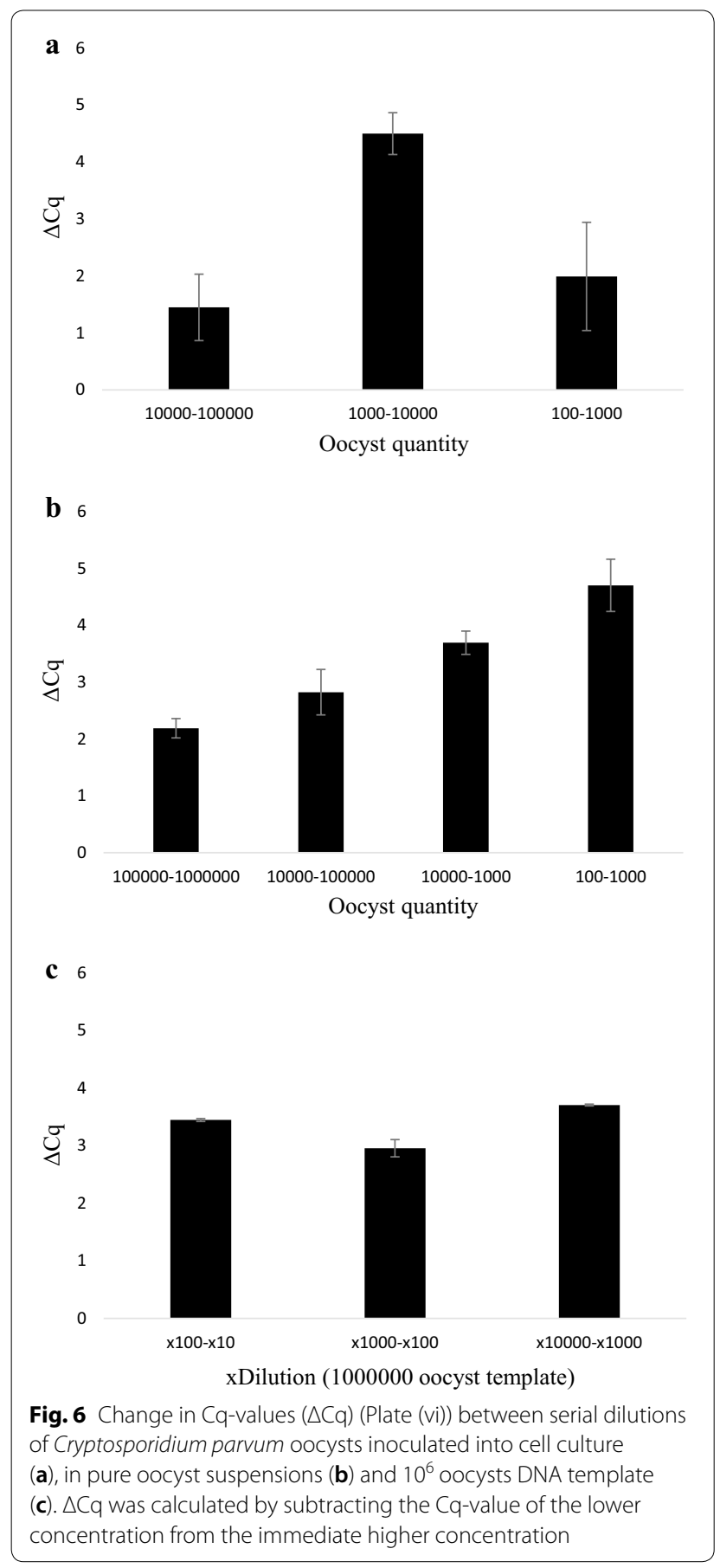

used in the present study (although PBS/well surface area was approximately the same). It is highly unlikely that the signal produced in the inactivated oocysts wells was due to contamination as blank wells that produced signal averaged Cq of $41.8 \pm 2$ across biological repeats opposed to $36.34 \pm 0.56$ for inactivated oocysts representing a 5.4 difference in Cq. Although direct comparison between plates is not appropriate, it should be
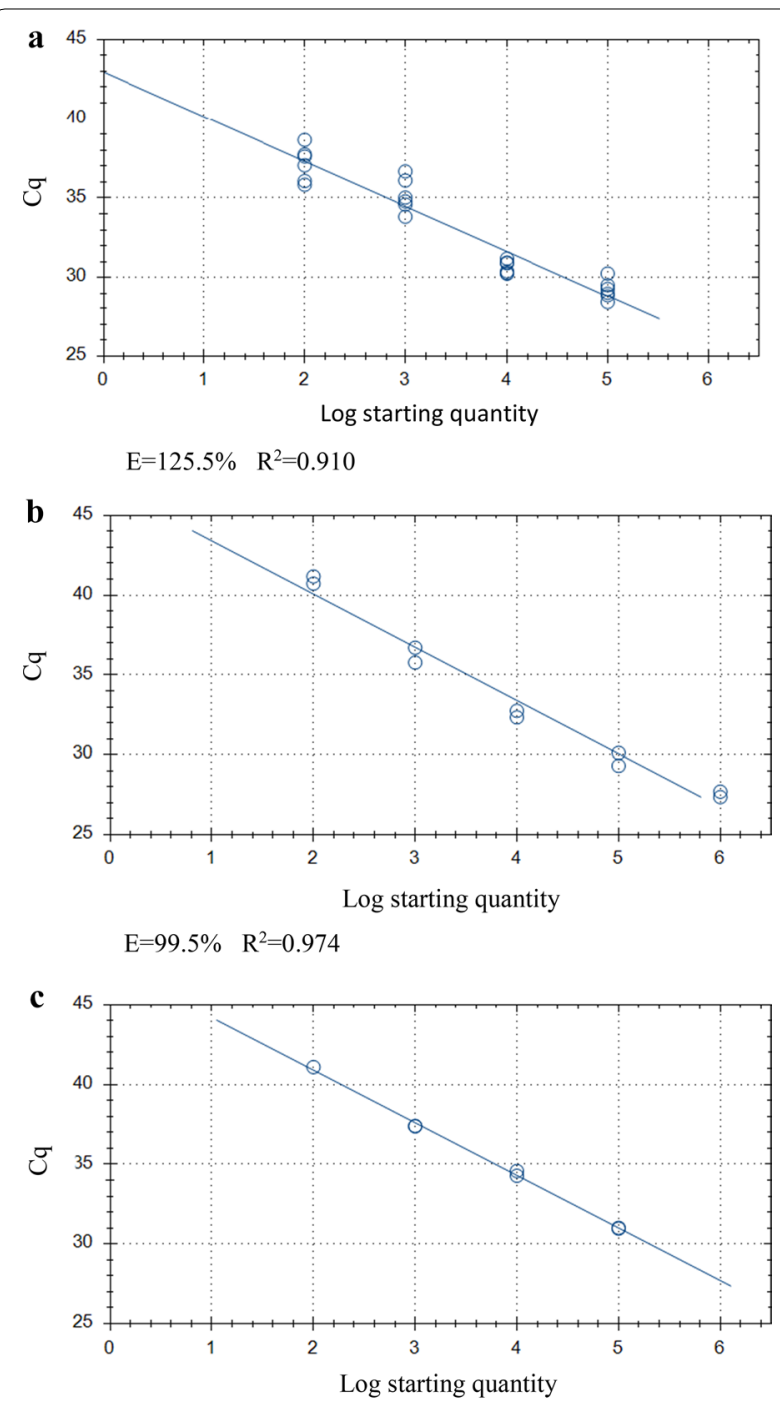

$\mathrm{E}=101.0 \% \quad \mathrm{R}^{2}=0.997$

Fig. 7 Standard curve generated for Plate (vi) from Cryptosporidium parvum oocysts inoculated onto HCT-8 cell monolayer plate B $\left(10^{5}-10^{2}\right)(\mathbf{a})$, pure oocyst serial dilution $B\left(10^{6}-10^{2}\right)(\mathbf{b})$ and equivalent template dilution $\mathrm{B}(\mathbf{c})$. Abbreviations: E, qPCR amplification efficiency; $R^{2}$, coefficient of variation

noted that 100 stock oocyst suspensions yielded either no signal, or Cq-values $>40$ which is indicative of oocyst invasion in the inactivated oocyst wells. If so, as $10^{5}$ inactivated oocysts were added to each well, this represents $99.9 \%$ oocyst inactivation and incubation for $10 \mathrm{~min}$ at 80 ${ }^{\circ} \mathrm{C}$ [23] may be preferable to $70{ }^{\circ} \mathrm{C}$ for $30 \mathrm{~min}$.

Dilution of the $10^{6}$ stock oocyst template did not yield significantly different Cq-values compared to stock oocyst dilutions except for the lower Cq-values in $10^{4}$ stock oocysts and its equivalent diluted template in Plate (vi). Detection limits of stock dilutions of suspended 
Table 5 Cq values of quantitative PCR Plate (vi)

\begin{tabular}{lll}
\hline Oocyst quantity & TR1 & TR2 \\
\hline $1,000,000$ & 27.70 & 27.36 \\
Mean TR \pm SD & $27.53 \pm 0.17$ & \\
100,000 & 30.12 & 29.32 \\
Mean TR \pm SD & $29.72 \pm 0.40$ & \\
10,000 & 32.75 & 32.34 \\
Mean TR \pm SD & $32.55 \pm 0.21$ & \\
1000 & 36.70 & 35.78 \\
Mean TR \pm SD & $36.24 \pm 0.46$ & 40.72 \\
100 & 41.17 & \\
Mean TR \pm SD & $40.95 \pm 0.23$ & na \\
MQ & na & \\
Mean TR \pm SD & na & \\
\hline
\end{tabular}

Notes: Pure oocyst serial dilution B. Baseline threshold 19.88 RFU

Abbreviations: $\mathrm{TR}$, technical repeat; $\mathrm{SD}$, standard deviation; na, no DNA amplification

Table 6 Cq values of quantitative PCR Plate (vi)

\begin{tabular}{llc}
\hline Template dilution & TR1 & TR2 \\
\hline$\times 10$ & 31.07 & 30.96 \\
Mean TR \pm SD & $30.99 \pm 0.03$ & \\
$\times 100$ & 34.28 & 34.58 \\
Mean TR \pm SD & $34.43 \pm 0.20$ & \\
$\times 1000$ & 37.37 & 37.4 \\
Mean TR \pm SD & $37.39 \pm 0.02$ & \\
$\times 10,000$ & na & \\
Mean TR \pm SD & na & \\
\hline
\end{tabular}

Notes: DNA template dilution of $10^{6}$ oocyst suspension B. Baseline threshold 19.88 RFU

Abbreviations: TR, technical repeat; SD, standard deviation; na, no DNA amplification

oocysts were higher than previously reported with similar qPCR designs yielding sensitivity down to one oocyst or lower [42, 43]. In addition to the reduced template quantity in the qPCR reaction described above, other factors, such as varying compositions of PCR master mix, primers, probes, water, oocyst strain and age may also account for this. Primer design and target regions appear to be particularly important. In one study comparing 16 different primer designs and target regions, only 7 enabled detection of $C$. parvum oocysts at numbers $<10^{4}$. Furthermore, as oocyst numbers in a sample decreased, the percentage of positive signals produced for a particular quantity of oocysts also reduced for certain primers [44]. It is important to note that all these factors are relative to the specific assay and as all conditions were uniform for all comparisons in this study, we feel confident that reduced detection limits in these assays do not
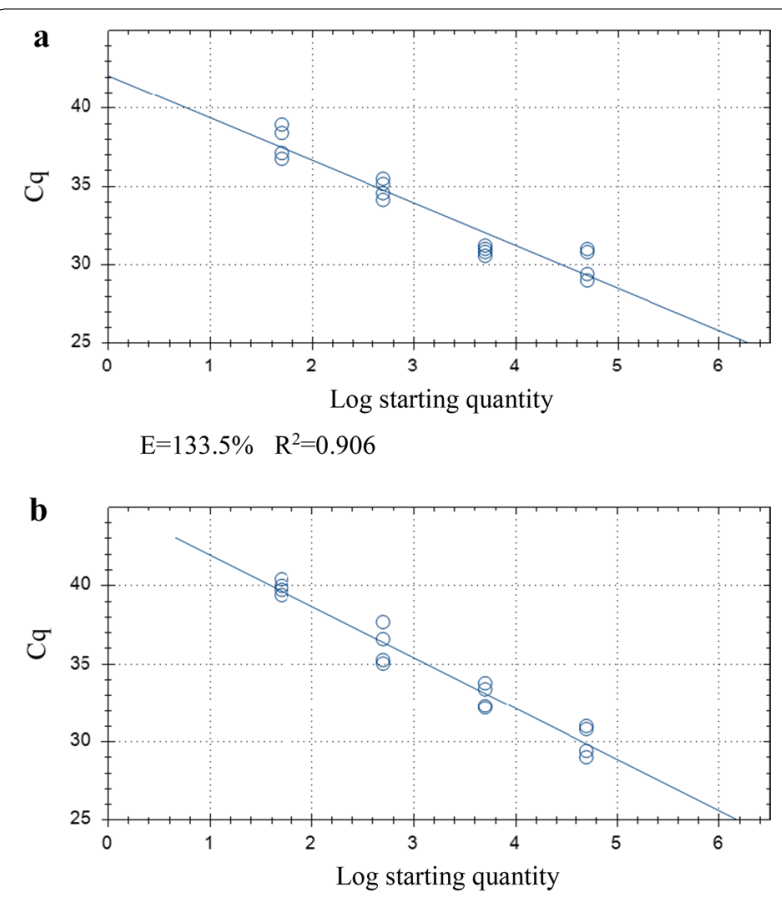

$\mathrm{E}=102.3 \% \quad \mathrm{R}^{2}=0.952$

Fig. 8 Standard curve generated for Plate (vii) from Cryptosporidium parvum oocysts inoculated onto HCT-8 cell monolayer plate $C$ $\left(5 \times 10^{4}-5 \times 10^{1}\right)(\mathbf{a})$ and cell culture serial dilution of $C$ and $D$ (×10-1000) (b). Abbreviations: E, qPCR amplification efficiency; $R^{2}$, coefficient of variation

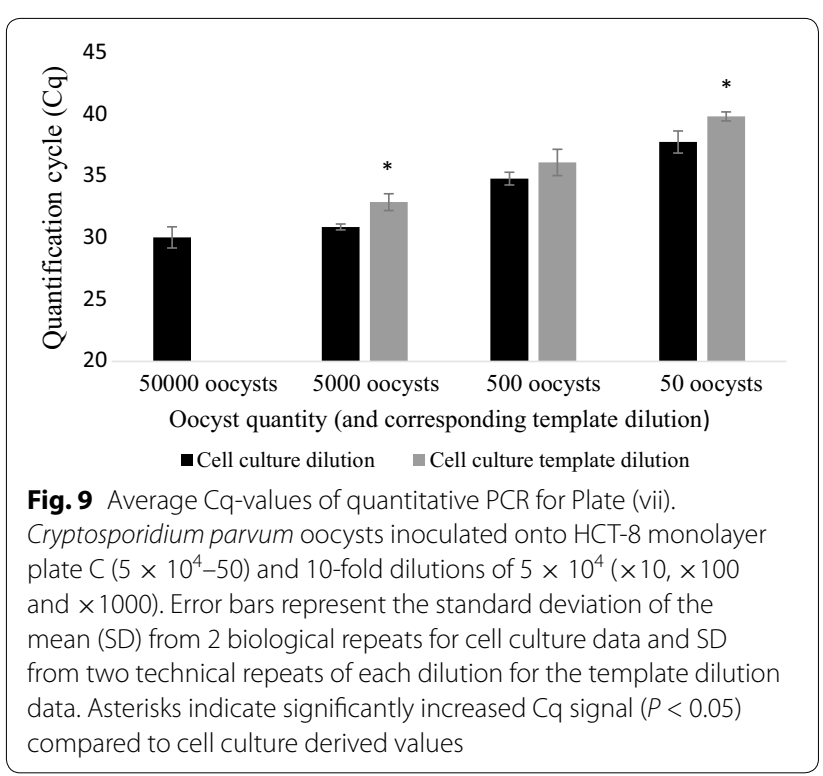

compromise the findings of our study. Prospective studies should focus on a better understanding of the differences between these different standard types at lower concentrations. 
Linearity values were also closer to 1 for both the stock oocyst dilutions and their equivalent templates than they were for cell culture derived templates. These linearity differences between the three DNA templates were maintained across all plates, further supporting the reproducibility of the assay. This is likely a consequence of the inherent variation encountered in C. parvum cell culture [9], which is supported by the increase in seeding variation revealed by flow cytometry in our study, with inter-well variation increasing at decreasing inoculate concentrations. As such, even for studies employing cell culture, stock oocysts or diluted template DNA may be desirable. Alternatively, considering the similarity of the template dilutions, serial dilutions of cell culture template DNA may provide the ideal standards for studies assessing Cryptosporidium growth.

As shown in Figs. 3 and 6, $\Delta$ Cq-values from cell culture derived oocysts were less uniform across inoculation ranges than their pure oocyst and oocyst DNA template dilution equivalents. Lower $\Delta$ Cq was observed in cell culture between $10^{5}$ and $10^{4}$ oocysts compared to $10^{4}$ and the subsequent dilutions $\left(10^{3}-10^{2}\right)$ in plates (i), (ii), (v) and (vi). The reduced viability of the cells inoculated with $10^{5}$ oocysts may in part be responsible for this finding; however, this was also observed in Plate (iv), where cell viability values of the $10^{5}$ samples analysed all had $\mathrm{OD}_{450}$ values within $75 \%$ of the blank control wells. This could suggest that possible inhibitors are present in the reaction mix; however, it is unlikely that the inhibitors originate from the host cells as these were seeded at the same density for all samples. The reduced $\Delta \mathrm{Cq}$ at the highest concentrations of stock oocysts and diluted template DNA was not as marked as in cell culture, although was still lower than differences between lower concentrations. This was initially thought to be a result of human DNA in the cell culture standards exceeding the binding capacity of the DNA extraction column resulting in $<100 \%$ C. parvum DNA present in the extracted template. However, DNA content in cell culture standards from plate $\mathrm{C}$ did not exceed $10.64 \pm 0.56 \mathrm{ng} / \mu \mathrm{l}$ (although it exceeded DNA content in equivalent quantities of freely suspended oocysts). The DNeasy ${ }^{\circledR}$ Blood \& Tissue Kit (Qiagen) is capable of extracting, on average, $30 \mu \mathrm{g}$ DNA from lysed $25 \mu \mathrm{g}$ tissue sample [45], greatly in excess of DNA quantities present in the cell culture standards. DNA saturation in the reaction mix is a further potential reason for this reduced $\Delta \mathrm{Cq}$ at higher concentrations, however this is challenged by $10^{6}$ stock oocysts producing significantly lower Cq-values than $10^{5}$ oocysts in cell culture.

Cq-values from serially diluted oocysts did not differ significantly from the DNA template dilutions of
$10^{6}$ oocysts and if inhibitors were present, lower Cqvalues would be expected in the diluted template [11]. However, amplification efficiency values in cell cultured oocysts were $>100 \%$ in all cell cultured standards in plates (v), (vi) and (vii) (Figs. 4a, 7a, 8a) with freely suspended oocysts and the DNA template dilutions of freely suspended oocysts and cell culture standards yielding amplification efficiency values closer to $100 \%$ on plates (vi) and (vii). Amplification efficiencies $>100 \%$ are indicative of polymerase inhibition [44], so it seems likely that this is, at least in part, responsible for the reduced linearity observed in the cell culture standards. Substances present in the HCT- 8 cells or trace inhibitors carried over from cell maintenance media may be responsible for this. On Plate (v), amplification efficiency was $>120$ for all standards. This high efficiency in the freely suspended oocyst standards and their equivalent diluted DNA template in addition to the cell culture standards may be a consequence of proteinase $\mathrm{K}$ inhibition carried over in this particular oocyst dilution series. Efficiency was not reduced in the equivalent DNA template dilutions on Plate (v) (Fig. 4c) as would be expected, but this is likely a consequence of no DNA signal present in the lowest two dilutions (resulting in only two data points on the standard curve), which is possibly due to the presence of these inhibitors.

It has been shown that $C$. parvum does not appear to multiply in a linear fashion in cell culture [15] and differing oocyst seeding density possibly affects parasite growth rates because of competition between parasites in the same well. In addition to polymerase inhibition, these factors may be responsible for lower $\Delta \mathrm{Cq}$ at high concentrations in cell culture standards. To what extent each of these factors is responsible for reduced linearity remains to be determined. These factors will also affect the template dilution of cell culture standards. If, for example parasite growth is less proliferative at higher seeding concentrations, dilutions of this template will not necessarily reflect DNA content obtained from lower inoculates. Indeed, diluted DNA template from 5 $\times 10^{4}$ oocyst cell culture standards on Plate (vii) yielded significantly less DNA at $\times 10$ and $\times 1000$ dilutions (the equivalent of $5 \times 10^{3}$ and 50 oocysts, respectively) than oocysts incubated in cell culture (Figs. 9, 10).

Although there is increased nucleic DNA content in cell culture derived standards, most likely an effect of asexual multiplication of the parasite in host cells, their suitability as standards over those derived from pure oocyst suspensions is not clear. The higher DNA content in cell culture derived standards will more accurately reflect DNA content in cell culture assays. However, the reduced linearity as a result of more 


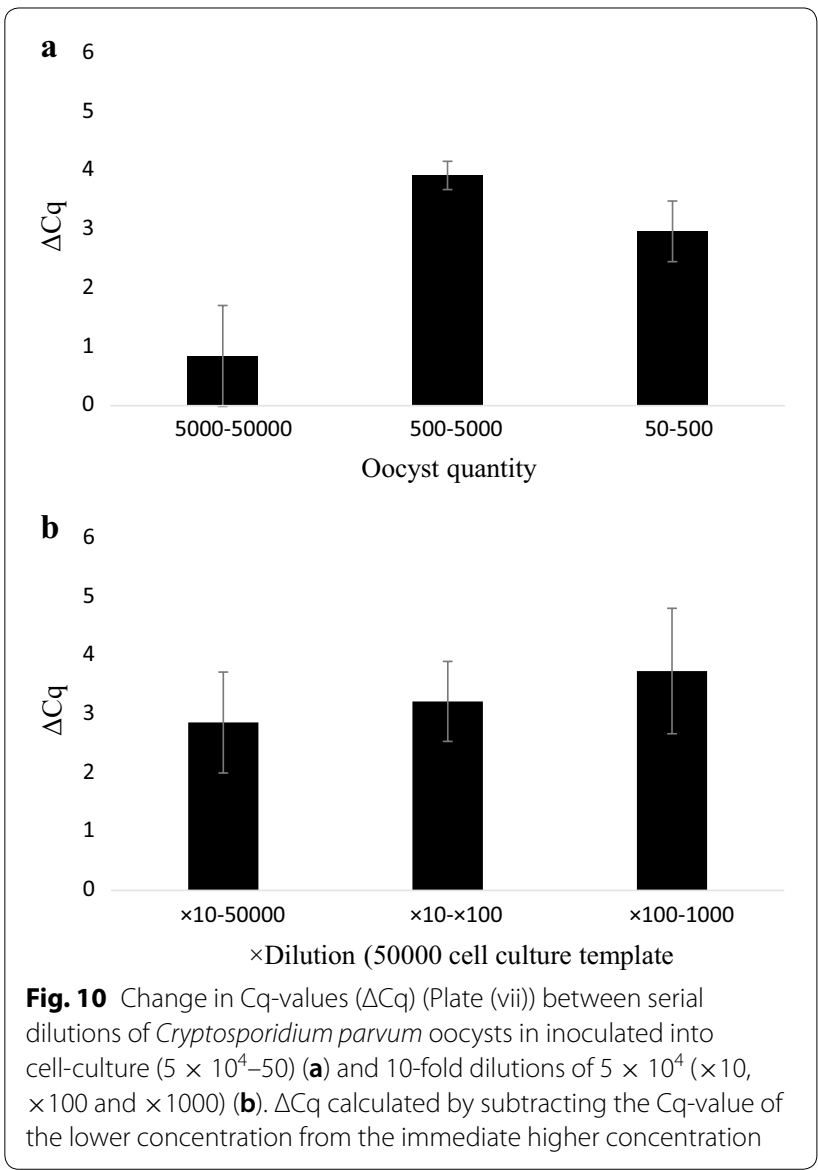

variable $\Delta$ Cq between oocyst concentrations (due to either oocyst seeding variation inherent in cell culture inoculations, polymerase inhibitors or different oocyst seeding densities onto the monolayer) will make it more difficult to interpret relative parasite inhibition based on the standard curve. Some studies have utilised oocyst suspensions as standards for Cryptosporidium cultured in cells or in axenic culture [22, 23]. As disinfection, development and drug screening studies are less dependent upon the absolute quantification of the parasite, rather, relative quantification, provided DNA standards remain the same across assays, it is possible to assess these aforementioned parameters [21, 41].

\section{Conclusions}

To facilitate inter-laboratory comparisons of qPCR results, standardised protocols are required including procedures for generating standard DNA templates if precise data are needed. Although numerous studies have reported DNA content from cell cultured C. parvum previously and these have been compared to in vivo models [24], in the present study, the clear suitability of template dilutions of stock oocysts for use as standards was established, despite a higher DNA content in cell culture templates at equivalent concentrations. Our results indicate that overall there was a consensus in the values obtained from the same templates analysed on different plates. The potential loss of cell viability at the highest seeding densities could suggest the use of inoculates < $10^{5}$ would be appropriate for cell culture assays. However, this should be considered in light of the propensity of increased variation and $\Delta \mathrm{Cq}$ in cell culture at lower oocyst inoculates. As only relative growth inhibition is required for many assays involving $C$. parvum it would appear the pure oocyst suspensions or diluted DNA templates may represent ideal standards at present. Since cell culture derived standards will more accurately reflect actual DNA content from parasite grown in cell culture however, there is a clear incentive for prospective study to focus on the mechanisms explaining this reduced linearity.

\section{Supplementary information}

Supplementary information accompanies this paper at https://doi. org/10.1186/s13071-019-3851-7.

Additional file 1: Table S1. Cq-values of quantitative PCR Plate (i). Cryptosporidium parvum oocysts inoculated onto HCT-8 cell monolayer plate A. Two technical repeats for each well (biological repeat). Abbreviations: TR, technical repeat; BR, biological repeat; SD, standard deviation.

Additional file 2: Table S2. Cq-values of quantitative PCR Plate (ii). Cryptosporidium parvum oocysts inoculated onto HCT-8 cell monolayer plate $B$. Two technical repeats for each well (biological repeat). Abbreviations: TR, technical repeat; BR, biological repeat; SD, standard deviation.

Additional file 3: Table S3. Cq-values of quantitative PCR Plate (iii). Pure C. parvum oocyst serial dilution A and B. Two technical repeats for each Eppendorf (biological repeat). Abbreviations: TR, technical repeat; SD, standard deviation.

Additional file 4: Table S4. Cq-values of quantitative PCR Plate (iv). Pure C. parvum oocyst serial dilution $A$ and $B$ and equivalent template dilution $A$ and B. Two technical repeats for each Eppendorf (biological repeat). Abbreviations: TR, technical repeat; SD, standard deviation.

\section{Abbreviations}

PCR: polymerase chain reaction; qPCR: quantitative polymerase chain reaction; HCT-8: human ileocecal adenocarcinoma; Cq: quantification cycle; ddPCR: digital droplet polymerase chain reaction; PBS: phosphate-buffered saline; DAPI/PI: 4',6-diamidino-2phenylindole/propidium iodide; ECACC: European collection of authenticated cell cultures; FBS: fetal bovine serum; EDTA: ethylenediaminetetraacetic acid; DMSO: dimethyl sulfoxide; WST-1: watersoluble tetrazolium assay; OD: optical density; ATL: animal tissue lysis; NTC: non-template controls; dsDNA: double stranded DNA; $\triangle \mathrm{Cq}$ : delta Cq (change in Cq-values); RFU: relative fluorescence units.

\section{Acknowledgements}

The authors would like to thank Kari Lybeck and Inger Heffernan at the Norwegian Veterinary Institute for their assistance with flow cytometry and cell culture.

\section{Authors' contributions}

IDW was involved in experimental design, laboratory work and writing the manuscript. BB and $\varnothing \varnothing$ performed with laboratory work and were involved in writing the manuscript. HLE was involved in experimental design and writing the manuscript. All authors read and approved the final manuscript. 


\section{Funding}

This study was financed by the Norwegian Veterinary Institute.

\section{Availability of data and materials}

The datasets used and/or analyzed during the present study are available from the corresponding author upon reasonable request.

\section{Ethics approval and consent to participate}

Not applicable.

\section{Consent for publication}

Not applicable.

\section{Competing interests}

The authors declare that they have no competing interests.

\section{Author details}

${ }^{1}$ Department of Animal Health and Food Safety, Norwegian Veterinary Institute, Ullevålsveien 68, 0454 Oslo, Norway. ${ }^{2}$ Norwegian Centre for Organic Agriculture, Gunnars veg 6, 6630 Tingvoll, Norway.

\section{Received: 3 September 2019 Accepted: 11 December 2019}

Published online: 19 December 2019

\section{References}

1. Thomson S, Hamilton C, Hope J, Katzer F, Mabbott N, Morrison L, et al. Bovine cryptosporidiosis: impact, host-parasite interaction and control strategies. Vet Res. 2017;48:42.

2. Striepen B. Parasitic infections: time to tackle cryptosporidiosis. Nature. 2013;503:189-91.

3. Bouwknegt M, Devleesschauwer B, Graham H, Robertson L, van der Giessen J. Prioritisation of food-borne parasites in Europe, 2016. Euro Surveill. 2016;23:17-00161.

4. Fayer R. Cryptosporidium: a water-borne zoonotic parasite. Vet Parasitol. 2004;126:37-56.

5. Casemore D, Watkins J. Review of disinfection and associated studies on Cryptosporidium. 1998. http://dwi.defra.gov.uk/research/completed-resea rch/reports/dwi0805.pdf. Accessed 10 Oct 2018.

6. Chalmers R, Giles M. Zoonotic cryptosporidiosis in the UK-challenges for control. J Appl Microbiol. 2010;109:1487-97.

7. Olias P, Dettwiler I, Hemphill A, Deplazes P, Steiner A, Meylan M. The significance of cryptosporidiosis for the health of calves in Switzerland. Schweiz Arch Tierhelkd. 2018;160:363-74.

8. Armson A, Meloni P, Reynoldson J, Thompson R. Assessment of drugs against Cryptosporidium parvum using a simple in vitro screening method. FEMS Microbiol Lett. 1999:178:227-33.

9. Rochelle P, Marshall M, Mead J, Johnson A, Korich D, Rosen J, et al. Comparison of in vitro cell culture and a mouse assay for measuring infectivity of Cryptosporidium parvum. J Appl Environ Microbiol. 2002;68:3809-17.

10. Shahiduzzaman M, Dyachenko V, Khalafalla R, Desouky A, Daugschies A. Effects of curcumin on Cryptosporidium parvum in vitro. Parasitol Res. 2009;105:1155-61.

11. Teichmann K, Kuliberda M, Schatzmayr G, Hadacek F, Joachim A. In vitro determination of anticryptosporidial activity of phytogenic extracts and compounds. Parasitol Res. 2012;111:231-40.

12. Gaur S, Kuhlenschmidt T, Kuhlenschmidt M, Andrade J. Effect of oregano essential oil and carvacrol on Cryptosporidium parvum infectivity in HCT-8 cells. Parasitol Int. 2018;67:170-5

13. Hijjawi N, Meloni B, Ryan U, Thompson R. Complete development and long-term maintenance of Cryptosporidium parvum human and cattle genotypes in cell culture. Int J Parasitol. 2001;31:1048-55.

14. Najdrowski M, Heckeroth A, Wackwitz C, Gawlowska S, Mackenstedt U, Kliemt D, et al. Development and validation of a cell culture based assay for in virto assessment of anticryptosporidial compounds. Parasitol Res. 2007;101:161-7.

15. Giovanni G, LeChevallier M. Quantitative-PCR assessment of Cryptosporidium parvum cell culture infection. Appl Environ Microbiol. 2005:71:1495-500.
16. King B, Keegan A, Robinson B, Monis P. Cryptosporidium cell culture infectivity assay design. Parasitology. 2011;138:671-81.

17. Current W, Haynes T. Complete development of Cryptosporidium in cell cultures. Science. 1984;224:603-5

18. Karanis $P$. The truth about in vitro culture of Cryptosporidium species. Parasitology. 2018;145:855-64

19. Hindsom B, Ness K, Masquelier D, Belgrader P, Heredia N, Makarewicz A, et al. High-throughput droplet digital PCR system for absolute quantification of DNA copy number. Anal Chem. 2011:83:8604-10.

20. Godiwala N, Vandewalle A, Ward H, Leav B. Quantification of in vitro and in vivo Cryptosporidium parvum infection by using real-time PCR. Appl Environ Microbiol. 2006;72:4484-8.

21. Yang R, Paparini A, Monis P, Ryan U. Comparison of next-generation droplet digital PCR (ddPCR) with quantitative PCR (qPCR) for enumeration of Crptosporidium oocysts in faecal samples. Int J Parasitol. 2014;44:1105-13.

22. Hijjawi N, Estcourt A, Yang R, Monis P, Ryan U. Complete development and multiplication of Cryptosporidium hominis in cell-free culture. Vet Parasitol. 2010;169:29-36

23. Keegan A, Fanok S, Monis P, Saint C. Cell culture-Taqman PCR assay for evaluation of Cryptosporidium parvum disinfection. Appl Environ Microbiol. 2003;69:2505-11.

24. Garvey M, Farrell H, Cormican M, Rowan N. Investigations of the relationship between the use of in vitro cell culture-quantitative PCR and a mouse-based bioassay for evaluating critical factors affecting the disinfection performance of pulsed UV light for treating Cryptosporidium parvum oocysts in saline. J Microbiol Meth. 2010;80:267-73.

25. Koken E, Darnault J, Jacobson A, Powelson D, Hendrickson W. Quantification of Cryptosporidium parvum in natural soil matrices and soil solutions using qPCR. J Microbial Meth. 2013:92:135-44.

26. MacDonald L, Sargent K, Armson A, Thompson A, Reynoldson J. The development of a real-time quantitative-PCR method for characterisation of a Cryptosporidium parvum in vitro culturing system and assessment of drug efficacy. Mol Biochem Parasitol. 2002;121:279-82.

27. Shahiduzzaman M, Dyachenko V, Obwaller A, Unglaube S, Daugschies A. Combination of cell culture and quantitative PCR for screening of drugs against Cryptosporidium parvum. Vet Parasitol. 2009;162:271-7.

28. Shahiduzzaman M, Dyachenko V, Keidel J, Schäschke R, Daugschies A Combination of cell culture and quantitative PCR (cc-qPCR) to assess disinfectants efficacy on Cryptosporidium oocysts under standardized conditions. Vet Parasitol. 2010:164:43-9.

29. Benamrouz S, Guyot K, Gazzola S, Mouray A, Chassat T, Delaire B, et al. Cryptosporidium parvum infection in SCID mice infected with only one oocyst: qPCR assessment of parasite replication in tissues and development of digestive cancer. PLOS ONE. 2012;7:e51232.

30. Leich G, He Q. Cryptosporidiosis—an overview. J Biomed Sci. 2011:25:1-16.

31. Borowski H, Thompson R, Armstrong T, Clode P. Morphological characterization of Cryptosporidium parvum life-cycle stages in an in vitro model system. Parasitology. 2010;137:13-26.

32. Rutledge R, Côte C. Mathematics of quantitative kinetic PCR and the application of standard curves. Nucleic Acids Res. 2003;31:e93.

33. Campbell A, Robertson L, Smith H. Viability of Cryptosporidium parvum oocysts: correlation of in vitro excystation with inclusion or exclusion of fluorogenic vital dyes. Appl Environ Microbiol. 1992;58:3488-93.

34. Petersen $\mathrm{H}$, Enemark $\mathrm{H}$. Viability assessment of Cryptosporidium oocysts by vital dyes: dry mounts overestimate the number of "ghost" oocysts. Foodborne Pathog Dis. 2018;15:141-4.

35. Slifko T, Friedman D, Rose J, Jakubowski W. An in vitro method for detecting infectious Cryptosporidium oocysts with cell culture. Appl Environ Microbiol. 1997:63:3669-75.

36. Morgan U, Constantine C, Forbes D, Thompson A. Differentiation between human and animal isolates of Cryptosporidium parvum using rDNA sequencing and direct PCR analysis. J Parasitol. 1997;83:825-30.

37. Amman $R$, Binder $B$, Olsen $R$, Chislom R, Devereaux R, Stahl D. Combination of 165 rRNA-targeted oligonucleotide probes with flow cytometry for analysing mixed microbial populations. Appl Environ Microbiol. 1990;56:1919-25.

38. BioRad. CFX Manager Version 31. Hercules: BioRad; 2019.

39. Bustin S, Benes V, Garson J, Hellemans J, Huggestt J, Kubista M, Mueller $R$, et al. The MIQE Guidelines: minimum information for publication of quantitative real-time PCR Experiments. Clin Chem. 2009:55:611-22. 
40. R Core Team (2019). R: a language and environment for statistical computing. Vienna: R Foundation for Statistical Computing. http://www.rproject.org/.

41. Heid C, Stevens J, Livak K, Williams P. Real time quantitative PCR. Genome Res. 1996;6:986-94.

42. Mary C, Chapey E, Dutoit K, Guyot K, Hasseine L, Jeddl F, et al. Multicentric evaluation of a new real-time PCR assay for quantification of Cryptosporidium spp. and identification of Cryptosporidium parvum and Cryptosporidium hominis. J Clin Microbiol. 2013;51:2556-63.

43. Yang R, Murphy C, Song Y, Ng-Hublin J, Estcourt A, Hijjawi N, et al. Specific and quantitative detection and identification of Cryptosporidium hominis and C. parvum in clinical and environmental samples. Exp Parasitol. 2013;135:142-7.
44. Leetz A, Sotiriadou I, Ongerth J, Karanis P. An evaluation of primers amplifying DNA targets for the detection of Cryptosporidium spp. using C. parvum HNJ-1 Japanese isolate in water samples. Parasitol Res. 2007; 101:951-62.

45. Qiagen. QIAamp ${ }^{\circledR}$ DNA Mini and Blood Mini Handbook. Qiagen. 2016 https://www.qiagen.com/ch/resources/download.aspx?id=62a20 0d6-faf4-469b-b50f-2b59cf738962\&lang=en. Accessed 31 July 2019.

\section{Publisher's Note}

Springer Nature remains neutral with regard to jurisdictional claims in published maps and institutional affiliations.
Ready to submit your research? Choose BMC and benefit from:

- fast, convenient online submission

- thorough peer review by experienced researchers in your field

- rapid publication on acceptance

- support for research data, including large and complex data types

- gold Open Access which fosters wider collaboration and increased citations

- maximum visibility for your research: over $100 \mathrm{M}$ website views per year

At BMC, research is always in progress.

Learn more biomedcentral.com/submissions 